\title{
Iliac bone marrow mast cells in relation to the renal osteodystrophy of patients treated by haemodialysis
}

\author{
H. A. ELLIS AND KATHLEEN M. PEART \\ From the Department of Pathology, University of Newcastle upon Tyne
}

SYNOPSIS Mast cells have been counted in iliac bone biopsies from patients with chronic renal failure treated by haemodialysis, and attempts made to relate mast cells to the various features of azotaemic renal osteodystrophy. There was a significant increase in the number of marrow mast cells in comparison with controls, and haemodialysis has no favourable effect on the marrow mast cell hyperplasia which occurs in chronic renal failure. There was a general tendency towards greater numbers of mast cells in cases with most marked osteitis fibrosa but it was not possible consistently to relate hyperparathyroidism to mast cell numbers. Patients treated by parathyroidectomy, aluminium hydroxide, or the newer vitamin $\mathrm{D}$ metabolites failed to show any consistent fall in marrow mast cell numbers in spite of improvement in the osteitis fibrosa. The number of marrow mast cells was related to the duration of haemodialysis and to the amount of osteoid present and inversely to the percentage mineralization of bone. It was not possible to identify any causal relationship between the presence or severity of osteomalacia and the number of mast cells in the haemodialysed patients although mast cell hyperplasia was also observed in patients with osteomalacia unassociated with renal disease.

In a previous paper (Peart and Ellis, 1975) we reported that there is an increase in the number of marrow mast cells in the iliac bone marrow of patients with chronic renal failure. Although mast cells occur in the marrow fibrous tissue associated with osteitis fibrosa, this is not the sole cause of the increase, since there is also an excess of mast cells in the non-fibrous marrow. We were unable to relate the number of mast cells to the presence or the severity of osteomalacia. The patients were in or near end-stage renal failure and although some had been treated by short-term peritoneal dialysis or by terminal haemodialysis none was on regular haemodialysis.

In the present paper we describe the results of observations on the numbers of iliac bone marrow mast cells in patients being treated by haemodialysis with parallel observations on the severity of osteitis fibrosa and osteomalacia, which are the two main histological abnormalities in azotaemic renal osteodystrophy (Ellis and Peart, 1973). We also report the results of serial observations on marrow mast cell numbers in patients treated by oral aluminium hydroxide or by parathyroidectomy to relieve hyperReceived for publication 28 January 1976 parathyroidism and in a small number of patients treated by the newly available vitamin $\mathrm{D}$ metabolites, 1, 25 dihydroxycholecalciferol $\left(1,25-(\mathrm{OH})_{2}\right.$ $\left.\mathrm{D}_{3}\right)$ and $1 \alpha$ hydroxycholecalciferol $\left(1-\alpha-\mathrm{OH}-\mathrm{D}_{3}\right)$. We have also determined the number of marrow mast cells in a group of patients with osteomalacia due to miscellaneous causes other than chronic renal failure.

\section{Material and Methods}

BONE

Transilial bone biopsy samples were examined from a total of 92 subjects. Seventy-nine of these were patients with chronic renal failure being treated by $\omega$ haemodialysis for periods varying from one week to 9 years 8 months. One of these had had a parathyroidectomy and a further three patients treated by parathyroidectomy were also studied. In addition there were 10 patients with osteomalacia not associated with renal disease.

Mast cells were counted in toluidine blue stained decalcified sections after fixation in neutral formalin $\mathbb{D}$ as previously described (Peart and Ellis, 1975). Further observations have shown that human mar- 
row mast cells are well preserved after formalin fixation and decalcification and that comparable numbers of mast cells are recognizable in decalcified and plastic embedded undecalcified sections. Triplicate counts made at three levels in the bone biopsy block at $100 \mu$ intervals have shown the method to be reproducible.

The severity of osteitis fibrosa on a scale of grades from 0 to 5 and the numbers of osteoclasts were determined in decalcified sections as previously described (Ellis and Peart, 1973), and the proportion of mineralized and non-mineralized bone was obtained by point-counting undecalcified sections (Garner and Ball, 1966; Ellis and Peart, 1972). Osteomalacia was diagnosed on the basis of an excess of osteoid with abnormally wide osteoid seams and a reduced calcification front (Ellis, 1973; Ellis and Peart, 1973).

\section{Results}

\section{TOTAL MARROW MAST CELLS}

The result of total mast cell counts in the marrow of iliac bone in 78 patients with renal failure treated by haemodialysis are summarized in table I, together with corresponding details of age, sex, duration of haemodialysis, severity of osteitis fibrosa, and the amounts of mineralized and non-mineralized bone. Figure 1 shows that the distribution of the number of marrow mast cells is not a normal one. There is a wide scatter of individual values with an excess of marrow mast cells (fig 2) in haemodialysed patients in comparison with the controls. In the haemodialysed patients the range is 0.41 to 193.99 mast cells per $\mathrm{mm}^{2}$ marrow with an arithmetic mean and a median of 28.02 and 20.39 per $\mathrm{mm}^{2}$, respectively. The mast cell number values approach the log normal rather than the normal distribution although the two patients with the lowest values do not conform. The mean and standard error for the $\log$ total number of mast cells is $1.27 \pm 0.05$ per $\mathrm{mm}^{2}$. In table II there is a statistical comparison, by the Mann-Whitney test, of the number of mast cells in control, non-dialysed, and haemodialysed subjects. There is a significant increase in the haemodialysed patients in comparison with the controls and with the non-dialysed renal patients, the last group including samples obtained by bone biopsy and at necropsy. There is no significant difference between the mast cell numbers in dialysed and nondialysed patients with renal failure if only bone biopsy samples are considered.

Relationship between numbers of mast cells and duration of haemodialysis

Plotting the number of mast cells against the duration of haemodialysis gives a wide scatter of points with a tendency towards higher values in those patients dialysed for long periods. Statistical analysis shows only a low order correlation with an improved relationship when the log total mast cell number is related to the duration of haemodialysis (table III).

Relationship between number of mast cells and mineralized and non-mineralized bone (tables III and IV)

In the haemodialysed patients there is a significant relationship between the number of mast cells and the amount of osteoid and the percentage mineralization of bone. There is no significant relationship between mast cell numbers and amounts of total or mineralized bone. The amount of mineralized bone is unrelated to the duration of haemodialysis but the percentage mineralization is reduced and the amount of osteoid increased with increasing time on dialysis. This raises the question whether the relationship between mast cell number and mineralization status is a direct one or results from concurrent relationships between both the number of mast cells and the mineralization status and the duration of dialysis. Determination of the partial correlation coefficients helps to unravel these possibilities. Table IV shows that omitting any possible effect of the number of mast cells has no significant effect on the highly significant correlations between both the amount of osteoid and the percentage bone mineralization and the duration of haemodialysis. On the other hand, the correlations between the number of mast cells and the percentage mineralization of bone or the amount of osteoid are greatly reduced by eliminating the effect of time on dialysis and are no longer significant. This suggests that there is probably no direct causal relationship between the mineralization status of the bone and the number of marrow mast cells. This is confirmed by the observation that the number of marrow mast cells is not strictly related to the presence of osteomalacia. Thus, excluding three cases of borderline osteomalacia, the values for the range, mean, and median for 39 cases with osteomalacia are $3 \cdot 86-193.99,32 \cdot 59$, and 24.51 mast cells per $\mathrm{mm}^{2}$ and the corresponding values for 36 cases without osteomalacia are respectively $0 \cdot 41-92 \cdot 61,24 \cdot 21$, and 18.69 mast cells per $\mathrm{mm}^{2}$. There is no significant difference between these two groups as judged by the Mann-Whitney test $(P>0 \cdot 10)$. The relationship between osteoid and mast cells holds for all of the 78 cases combined and for those 39 cases with osteomalacia but not for those 36 without osteomalacia $(P>0.05)$. Likewise the relationship between osteoid and duration of haemodialysis holds only for all cases combined or those with osteomalacia $(\mathrm{P}<0.001)$. 


\begin{tabular}{|c|c|c|c|c|c|c|c|c|c|c|c|}
\hline Case No. & Age & Sex & $H D t$ & $M C$ & $T B$ & $M B$ & $O$ & $\% M I N$ & $L$ & $O M$ & $O F G$ \\
\hline 1 & 31 & $\mathbf{F}$ & $0 \cdot 25$ & $20 \cdot 51$ & $15 \cdot 2$ & 14.9 & 0.32 & $97 \cdot 9$ & 2 & - & 2 \\
\hline 2 & 36 & $\mathbf{M}$ & 0.25 & 1.05 & $23 \cdot 2$ & $22 \cdot 6$ & 0.56 & $97 \cdot 4$ & 3 & - & 1.5 \\
\hline 3 & 51 & $\mathbf{F}$ & 0.75 & 25.61 & 13.7 & 13.5 & 0.19 & 98.6 & 2 & - & 1.5 \\
\hline 4 & 37 & $\mathbf{M}$ & 1 & $13 \cdot 27$ & $19 \cdot 2$ & $18 \cdot 8$ & 0.41 & 97.9 & 2 & - & 0 \\
\hline 5 & 39 & $\mathbf{F}$ & 1 & 41.63 & $36 \cdot 5$ & $36 \cdot 4$ & 0.14 & 99.6 & 2 & - & 0 \\
\hline 6 & 41 & $\mathbf{M}$ & 1 & $12 \cdot 59$ & $15 \cdot 6$ & $15 \cdot 3$ & 0.29 & $98 \cdot 1$ & 2 & - & 0 \\
\hline 7 & 49 & $F$ & 1 & 0.41 & $24 \cdot 2$ & $23 \cdot 8$ & 0.44 & $98 \cdot 2$ & 2 & - & 1 \\
\hline 8 & 50 & $\mathbf{M}$ & 1 & 14.91 & $21 \cdot 4$ & 20.2 & $1 \cdot 18$ & $94 \cdot 5$ & 4 & - & 1.5 \\
\hline 9 & 18 & $\mathbf{M}$ & 2 & $20 \cdot 25$ & $17 \cdot 4$ & $15 \cdot 8$ & 1.56 & $90 \cdot 8$ & 5 & $\pm \mathbf{B}$ & 1 \\
\hline 10 & 26 & $\mathrm{~F}$ & 2 & $9 \cdot 55$ & 23.7 & $23 \cdot 4$ & 0.29 & $98 \cdot 8$ & 3 & $=$ & 1 \\
\hline 11 & 32 & $\mathbf{M}$ & 2 & $5 \cdot 37$ & $20 \cdot 2$ & $20 \cdot 1$ & 0.07 & $99 \cdot 7$ & 3 & - & 0 \\
\hline 12 & 49 & $\mathrm{~F}$ & 2 & 5.47 & $22 \cdot 1$ & 18.7 & $3 \cdot 39$ & $84 \cdot 6$ & 4 & $\pm \mathbf{B}$ & 1.5 \\
\hline 13 & 17 & $F$ & 3 & 17.62 & $11 \cdot 7$ & $9 \cdot 4$ & $2 \cdot 27$ & $80 \cdot 3$ & 4 & $\pm \mathbf{B}$ & 4 \\
\hline 14 & 35 & $F$ & 3 & 25.07 & $31 \cdot 1$ & $27 \cdot 3$ & $3 \cdot 71$ & $88 \cdot 1$ & 5 & + & 2 \\
\hline 15 & 46 & $\mathbf{M}$ & 5 & $9 \cdot 40$ & 20.6 & $19 \cdot 4$ & $1 \cdot 13$ & $94 \cdot 5$ & 3 & - & 3 \\
\hline 16 & 50 & $\mathbf{M}$ & 5 & $29 \cdot 20$ & $25 \cdot 7$ & $21 \cdot 3$ & $4 \cdot 44$ & $82 \cdot 7$ & 6 & + & 3 \\
\hline 17 & 56 & $\mathbf{M}$ & 5 & 32.71 & 25.9 & $24 \cdot 0$ & 1.88 & 92.7 & 4 & - & $2 \cdot 5$ \\
\hline 18 & 40 & $\mathbf{M}$ & 6 & 5.81 & $23 \cdot 7$ & $20 \cdot 6$ & 3.04 & $87 \cdot 2$ & 5 & + & 1 \\
\hline 19 & 42 & $F$ & 7 & $44 \cdot 12$ & 26.7 & $24 \cdot 4$ & $2 \cdot 23$ & $91 \cdot 6$ & 5 & + & $2 \cdot 5$ \\
\hline 20 & 61 & $F$ & 8 & 5.05 & $21 \cdot 0$ & $20 \cdot 8$ & 0.19 & $99 \cdot 1$ & 2 & - & 0 \\
\hline 21 & 25 & $\mathrm{~F}$ & 9 & 5.97 & $17 \cdot 9$ & $17 \cdot 8$ & 0.07 & $99 \cdot 6$ & 1 & - & 0 \\
\hline 22 & 36 & M & 9 & $10 \cdot 71$ & 32.2 & 29.0 & $3 \cdot 21$ & $90 \cdot 0$ & 5 & + & $2 \cdot 5$ \\
\hline 23 & 53 & $\mathbf{M}$ & 9 & $64 \cdot 30$ & 14.9 & 14.9 & 0.00 & $100 \cdot 0$ & 2 & - & 0 \\
\hline 24 & 28 & $\mathbf{M}$ & 10 & $21 \cdot 47$ & $17 \cdot 7$ & $17 \cdot 3$ & 0.37 & 97.9 & $12^{*}$ & + & 0 \\
\hline 25 & 47 & $\mathbf{M}$ & 10 & $59 \cdot 36$ & $11 \cdot 4$ & $10 \cdot 5$ & 0.86 & $92 \cdot 4$ & 6 & + & 1.5 \\
\hline 26 & 27 & M & 11 & $48 \cdot 18$ & $14 \cdot 5$ & 13.5 & 1.00 & $93 \cdot 1$ & 5 & + & 1.5 \\
\hline 27 & 31 & M & 11 & 6.79 & $22 \cdot 1$ & 194 & 2.74 & $87 \cdot 6$ & 5 & + & 2 \\
\hline 28 & 31 & $\mathrm{~F}$ & 12 & $35 \cdot 42$ & 15.0 & 14.9 & 0.09 & 99.4 & 2 & - & 1.5 \\
\hline 29 & 41 & $\mathbf{M}$ & 12 & $9 \cdot 75$ & $25 \cdot 2$ & $21 \cdot 8$ & $3 \cdot 43$ & $86 \cdot 4$ & 6 & + & 2 \\
\hline 30 & 45 & $\mathbf{F}$ & 12 & $8 \cdot 23$ & 310 & $25 \cdot 4$ & 5.64 & $81 \cdot 8$ & 8 & + & 1.5 \\
\hline 31 & 23 & $F$ & 13 & $36 \cdot 70$ & $29 \cdot 5$ & $28 \cdot 8$ & 0.72 & $97 \cdot 5$ & 3 & - & 3 \\
\hline 32 & 41 & $\mathrm{~F}$ & 13 & $7 \cdot 15$ & $28 \cdot 2$ & $27 \cdot 3$ & 0.88 & 96.9 & 2 & - & 3 \\
\hline 33 & 52 & $\mathbf{M}$ & 13 & $18 \cdot 66$ & $22 \cdot 2$ & $18 \cdot 6$ & 3.52 & $84 \cdot 1$ & 5 & + & 3.5 \\
\hline 34 & 54 & $\mathbf{F}$ & 13 & $74 \cdot 82$ & $21 \cdot 1$ & $21 \cdot 1$ & 0.00 & $100 \cdot 0$ & 1 & - & 0 \\
\hline 35 & 32 & $\mathbf{M}$ & 14 & 8.65 & $18 \cdot 6$ & $17 \cdot 1$ & 1.44 & $92 \cdot 2$ & 4 & - & 1 \\
\hline 36 & 53 & $\mathbf{F}$ & 14 & $16 \cdot 54$ & $9 \cdot 6$ & $9 \cdot 3$ & 0.38 & $96 \cdot 1$ & 5 & + & 1.5 \\
\hline 37 & 37 & $\mathbf{M}$ & 15 & $10 \cdot 55$ & 18.5 & $17 \cdot 7$ & 0.86 & $95 \cdot 3$ & 5 & + & 1 \\
\hline 38 & 47 & $\mathbf{M}$ & 16 & $24 \cdot 51$ & $17 \cdot 4$ & $17 \cdot 1$ & 0.25 & 98.5 & 6 & + & 0 \\
\hline 39 & 47 & $\mathbf{F}$ & 16 & $48 \cdot 28$ & $31 \cdot 3$ & 29.0 & $2 \cdot 24$ & $92 \cdot 8$ & 4 & - & $2 \cdot 5$ \\
\hline 40 & 37 & M & 18 & 18.61 & $15 \cdot 3$ & $14 \cdot 6$ & 0.70 & $95 \cdot 5$ & 2 & - & 2 \\
\hline 41 & 44 & $\mathbf{M}$ & 19 & $14 \cdot 16$ & $28 \cdot 2$ & $26 \cdot 6$ & 1.55 & $94 \cdot 5$ & 3 & - & $2 \cdot 5$ \\
\hline 42 & 53 & $\mathbf{F}$ & 20 & 23.48 & $13 \cdot 4$ & $12 \cdot 2$ & 1.21 & 91.0 & 5 & + & 1 \\
\hline 43 & 41 & $\mathbf{M}$ & 21 & 92.43 & $25 \cdot 0$ & $23 \cdot 1$ & 1.96 & $92 \cdot 2$ & 5 & + & 2.5 \\
\hline 44 & 41 & $\mathbf{F}$ & 21 & 3.86 & $28 \cdot 6$ & $25 \cdot 1$ & 3.43 & $88 \cdot 0$ & 6 & + & 1 \\
\hline 45 & 55 & $\mathbf{F}$ & 21 & $15 \cdot 15$ & $24 \cdot 2$ & $21 \cdot 4$ & 2.72 & $88 \cdot 7$ & 5 & + & 1 \\
\hline 46 & 47 & $\mathbf{F}$ & 22 & $34 \cdot 76$ & $17 \cdot 5$ & $16 \cdot 7$ & 0.88 & 95.0 & 5 & + & 2 \\
\hline 47 & 42 & $\mathbf{M}$ & 24 & $52 \cdot 14$ & $21 \cdot 7$ & $17 \cdot 1$ & $4 \cdot 56$ & 78.9 & 5 & + & 3 \\
\hline 48 & 28 & $\mathbf{M}$ & 27 & $4 \cdot 86$ & $31 \cdot 7$ & $31 \cdot 2$ & 0.51 & 98.4 & 2 & - & 2 \\
\hline 49 & 16 & $\mathbf{M}$ & 28 & $50 \cdot 20$ & $21 \cdot 2$ & $17 \cdot 8$ & $3 \cdot 39$ & $84 \cdot 0$ & 8 & + & $3 \cdot 5$ \\
\hline 50 & 36 & $\mathbf{F}$ & 28 & 48.57 & $52 \cdot 7$ & $51 \cdot 8$ & 0.96 & 98.2 & 4 & - & $4 \cdot 5$ \\
\hline 51 & 29 & $\mathbf{M}$ & 31 & 6.06 & $22 \cdot 8$ & 20.7 & $2 \cdot 13$ & 90.7 & 6 & + & 1.5 \\
\hline 52 & 32 & $\mathbf{F}$ & 31 & $21 \cdot 13$ & $27 \cdot 0$ & $26 \cdot 1$ & 0.95 & $96 \cdot 5$ & 3 & - & 2 \\
\hline 53 & 49 & $\mathbf{M}$ & 32 & 11.65 & $20 \cdot 1$ & $19 \cdot 0$ & $1 \cdot 16$ & $94 \cdot 3$ & 5 & + & 1 \\
\hline 54 & 52 & $\mathbf{M}$ & 34 & 9.94 & $18 \cdot 5$ & $18 \cdot 4$ & 0.11 & $99 \cdot 4$ & 2 & - & 0 \\
\hline 55 & 25 & $\mathbf{M}$ & 36 & $26 \cdot 30$ & 33.9 & $33 \cdot 4$ & 0.50 & 98.5 & 2 & - & $1 \cdot 5$ \\
\hline 56 & 30 & $\mathbf{F}$ & 36 & 193.99 & $36 \cdot 7$ & 30.7 & 6.04 & $83 \cdot 6$ & 10 & + & $3 \cdot 5$ \\
\hline 57 & 32 & $F$ & 36 & 8.05 & $26 \cdot 3$ & $23 \cdot 2$ & $3 \cdot 10$ & $88 \cdot 2$ & 10 & + & 1 \\
\hline 58 & 26 & $F$ & 39 & $18 \cdot 37$ & $19 \cdot 0$ & $17 \cdot 8$ & $1 \cdot 14$ & 94.0 & 7 & + & 1 \\
\hline 59 & 46 & $\mathbf{M}$ & 39 & $7 \cdot 44$ & $12 \cdot 2$ & 12.0 & $0 \cdot 19$ & $98 \cdot 4$ & 3 & - & 0 \\
\hline 60 & 57 & $\mathbf{F}$ & 40 & $39 \cdot 28$ & $24 \cdot 8$ & $24 \cdot 6$ & $0 \cdot 18$ & $99 \cdot 3$ & 4 & - & 0 \\
\hline 61 & 56 & $\mathbf{M}$ & 41 & $28 \cdot 74$ & $35 \cdot 5$ & $30 \cdot 4$ & 5.08 & $85 \cdot 7$ & 7 & + & $2 \cdot 5$ \\
\hline 62 & 48 & $\mathbf{M}$ & 42 & $18 \cdot 76$ & $26 \cdot 4$ & $25 \cdot 3$ & 1.05 & $96 \cdot 0$ & 4 & - & $2 \cdot 5$ \\
\hline 63 & 32 & $\mathbf{F}$ & 48 & $7 \cdot 44$ & $26 \cdot 2$ & $23 \cdot 8$ & $2 \cdot 44$ & $90 \cdot 7$ & 5 & + & $2 \cdot 5$ \\
\hline 64 & 32 & $F$ & 50 & 13.60 & $41 \cdot 2$ & 35.9 & $5 \cdot 34$ & $87 \cdot 1$ & 6 & + & 3 \\
\hline 65 & 47 & $\mathbf{M}$ & 50 & 30.94 & $26 \cdot 0$ & $24 \cdot 5$ & 1.50 & $94 \cdot 2$ & 6 & + & 0 \\
\hline 66 & 49 & $\mathbf{M}$ & 50 & $25 \cdot 39$ & $21 \cdot 9$ & $21 \cdot 3$ & 0.57 & $97 \cdot 4$ & 8 & + & 1 \\
\hline 67 & 29 & $\mathbf{F}$ & 51 & $40 \cdot 60$ & $26 \cdot 8$ & $23 \cdot 1$ & 3.74 & $86 \cdot 0$ & 4 & + & 2.5 \\
\hline 68 & 38 & $\mathbf{M}$ & 51 & 92.61 & $28 \cdot 8$ & $26 \cdot 0$ & 2.79 & $90 \cdot 3$ & 3 & - & 3 \\
\hline 69 & 52 & $\mathbf{M}$ & 52 & $26 \cdot 13$ & 20.5 & $20 \cdot 2$ & $0 \cdot 28$ & $98 \cdot 6$ & 4 & - & 3 \\
\hline 70 & 43 & $\mathbf{M}$ & 55 & 35.06 & 26.5 & $25 \cdot 4$ & $1 \cdot 11$ & 95.8 & 2 & - & $2 \cdot 5$ \\
\hline 71 & 46 & $\mathbf{M}$ & 58 & $8 \cdot 31$ & $10 \cdot 5$ & 9.9 & 0.59 & $94 \cdot 4$ & 5 & + & 0 \\
\hline 72 & 44 & $\mathbf{M}$ & 59 & 51.54 & 37.0 & $27 \cdot 6$ & $9 \cdot 41$ & 74.5 & 6 & + & 4 \\
\hline 73 & 48 & $F$ & 60 & 22.21 & $32 \cdot 2$ & $30 \cdot 9$ & 1.26 & $96 \cdot 1$ & 2 & - & $3 \cdot 5$ \\
\hline 74 & 20 & $\mathbf{M}$ & 63 & $13 \cdot 15$ & $25 \cdot 8$ & $25 \cdot 2$ & 0.54 & 97.9 & 4 & - & $2 \cdot 5$ \\
\hline 75 & 30 & $F$ & 67 & $64 \cdot 35$ & $47 \cdot 4$ & $36 \cdot 1$ & $11 \cdot 22$ & $76 \cdot 3$ & 6 & + & $4 \cdot 5$ \\
\hline 76 & 28 & $\mathbf{M}$ & 81 & $26 \cdot 27$ & $21 \cdot 5$ & $19 \cdot 0$ & $2 \cdot 50$ & 88.4 & 7 & + & 3 \\
\hline 77 & 39 & $\mathbf{F}$ & 84 & $92 \cdot 13$ & 21.9 & $12 \cdot 3$ & $9 \cdot 54$ & 56.4 & 9 & + & $1 \cdot 5$ \\
\hline 78 & 46 & $\mathbf{M}$ & 116 & $32 \cdot 47$ & $18 \cdot 8$ & $12 \cdot 1$ & 6.74 & $64 \cdot 2$ & 6 & + & $3 \cdot 5$ \\
\hline
\end{tabular}

Table I Details of numbers of marrow mast cells, duration of haemodialysis, mineralization of bone, and severity of osteitis fibrosa in 78 patients with chronic renal failure treated by haemodialysis

*Cortical wide seam.

HDt, duration of haemodialysis in months; MC, total number of mast cells per $\mathrm{mm}^{2}$ marrow; TB, MB, O, percentage of measured area of iliac $O$ bone occupied by total bone, mineralized bone, and osteoid, respectively; \% MIN, percentage mineralization of cancellous bone; L, maximum number of birefringent lamellae in osteoid seams; OM, osteomalacia + or $-; \pm \mathbf{B}$, borderline osteomalacia; OFG $=$ osteitis fibrosa grade of severity (scale 0-5). 


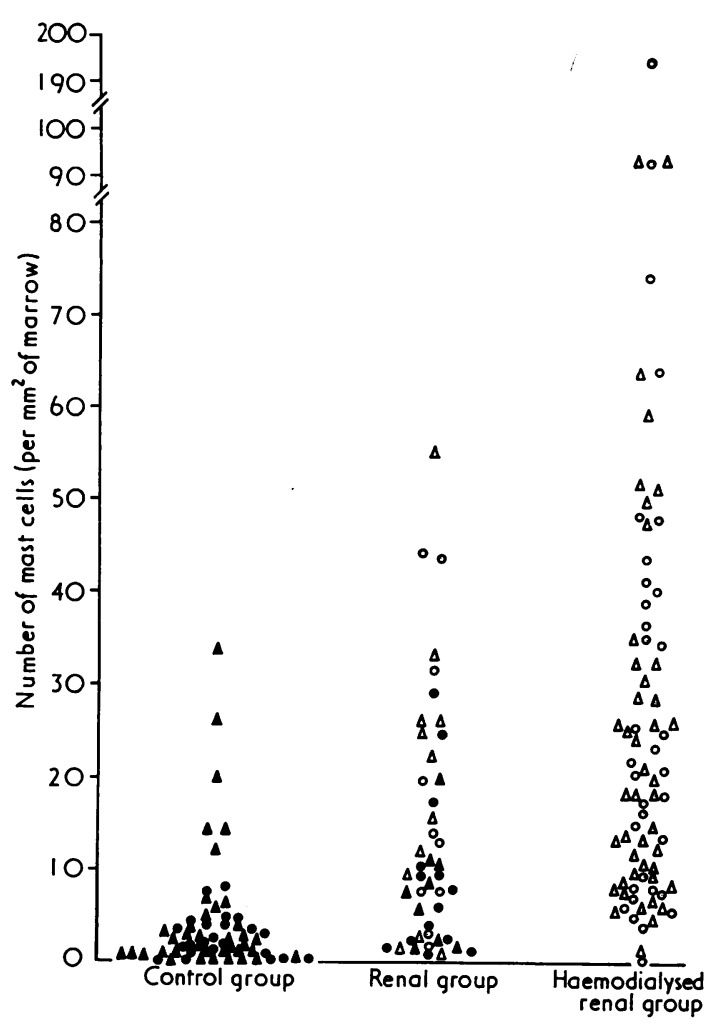

Fig 1 Distribution of numbers of iliac bone marrow mast cells in 78 haemodialysed patients compared with 45 non-dialysed patients with chronic renal failure and 61 controls:

$\triangle \Delta$ males, biopsy and necropsy samples;

- females, biopsy and necropsy samples.

Serial observations on a group of patients developing osteomalacia

In 16 patients osteomalacia was noted to develop between serial bone biopsies. Details of the changes in mast cell numbers and the time intervals between the biopsies are summarized in table V. Some of these patients had been treated by oral aluminium hydroxide and had developed osteomalacia over a relatively short period. Using a 'within patient' test there is a significant increase in mast cells when all 16 patients or those nine not treated by aluminium hydroxide are considered $(\mathrm{P}<0.01$ and $<0.02$, respectively) but not in the case of the seven aluminium hydroxide treated patients $(P>0 \cdot 10)$. This combination of events throws doubt on the significance of the association between increase in mast cell numbers and the development of osteomalacia and suggests that other factors may be important. Changes in osteitis fibrosa in these 16 patients are variable and do not appear to be related to the number of mast cells. The time interval between serial bone biopsies may be the common factor associated with the development of osteomalacia and increase in mast cells in the marrow as already suggested. There is certainly a shorter mean time interval between biopsies in the case of the patients treated by aluminium hydroxide $(8.3 \pm 1.4$ compared with $22.4 \pm \mathbf{4 . 2}$ months) and this difference is significant $(P<0.02)$.

Relationship between number of mast cells and severity of osteitis fibrosa

Since the osteitis fibrosa gradings are semiquantitative and non-parametric it is not possible to calculate directly any relationship between mast cell numbers and the severity of osteitis fibrosa using statistical methods based on the normal distribution. When the numbers or log numbers of mast cells are plotted in relation to the severity of osteitis fibrosa there is a wide scatter of mast cell values in each grade (fig 3 ). However, comparison of the mean numbers of mast cells in bones with osteitis fibrosa grade 0 to 2 and grades 2.5 to 4.5 reveals a significant difference $(P<0.001)$ by the Mann-Whitney test. That there is an association between the number of mast cells and the osteitis fibrosa grade is further supported by Spearman's rank test (Snedecor and Cochran, 1971) which gives values of 3.191 and 0.364 for $Z$ and $r_{s}$ respectively $(P<0.01)$. Determination of the mean and standard error of the log number of marrow mast cells in each grade of osteitis fibrosa and subsequent comparisons between the various groups show no instance of a significant difference in the means of immediately adjacent groups and a significant difference is obtained only when comparisons are made between widely separated groups such as grade 1 with grades $2 \cdot 5,3,3 \cdot 5$, and $4 \cdot 5$, and grade 2 with grades $3 \cdot 5$ and $4 \cdot 5$ (table VI).

\section{EFFECT OF TREATMENT WITH PHOSPHATE BINDER}

Oral aluminium hydroxide with or without calcium carbonate may be used as a phosphate binder in an attempt to lower serum phosphate and raise serum calcium, thereby reducing the output of parathormone and the severity of any osteitis fibrosa present. If there is any causal relationship between hyperparathyroidism and the numbers of marrow mast cells one would expect to be able to detect differences in mast cell numbers between groups of nontreated and aluminium hydroxide treated patients. Accordingly the 78 patients have been divided into two groups comprising 16 who had received aluminium hydroxide before bone biopsy and 61 who had not. The remaining patient had been treated by 


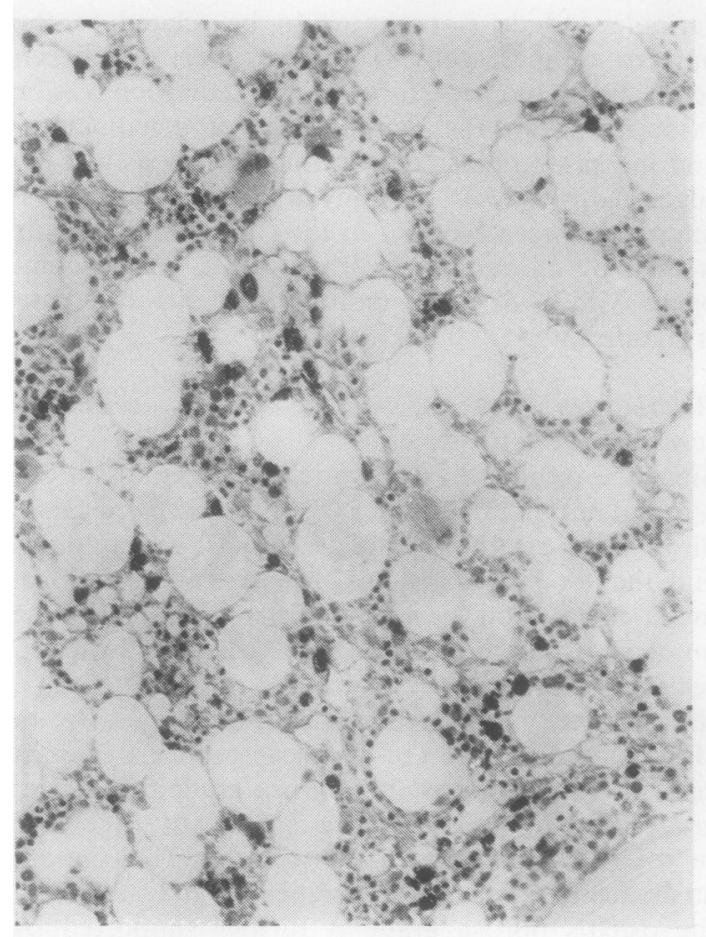

a

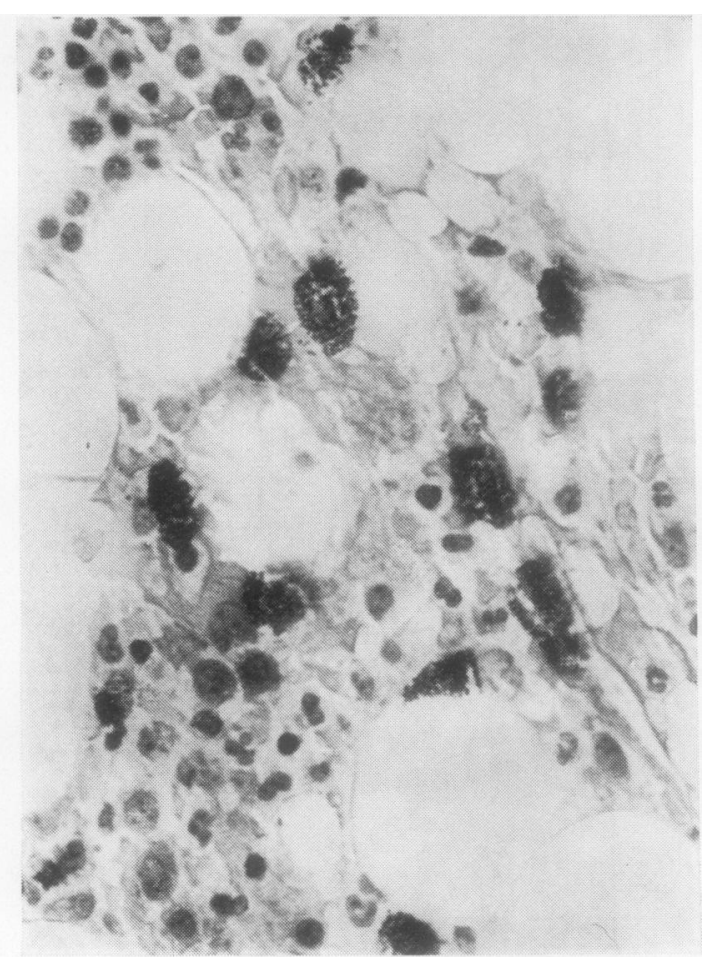

b

Fig 2 Case 56. Increase in number of marrow mast cells in a patient with chronic renal failure treated by haemodialysis. Decalcified, toluidine blue $(a) \times 160(b) \times 560$.

parathyroidectomy and has been excluded. Previous bone biopsies were available in all 16 of those treated by aluminium hydroxide, and in six there had been a reduction in the severity of osteitis fibrosa. Mast cell numbers in both groups are higher than in the controls (table $\mathrm{I}$ ) but there is no significant difference between the groups $(P>0.05$ by the Mann-Whitney ranking test of unconverted data and by comparison of means of the log numbers of mast cells by Student's $t$ test).

To study further the possible effect of aluminium hydroxide-induced reduction in osteitis fibrosa on mast cell numbers more detailed observations have been made in 20 patients with iliac bone biopsies available before and after treatment by oral calcium carbonate and aluminium hydroxide. Details of

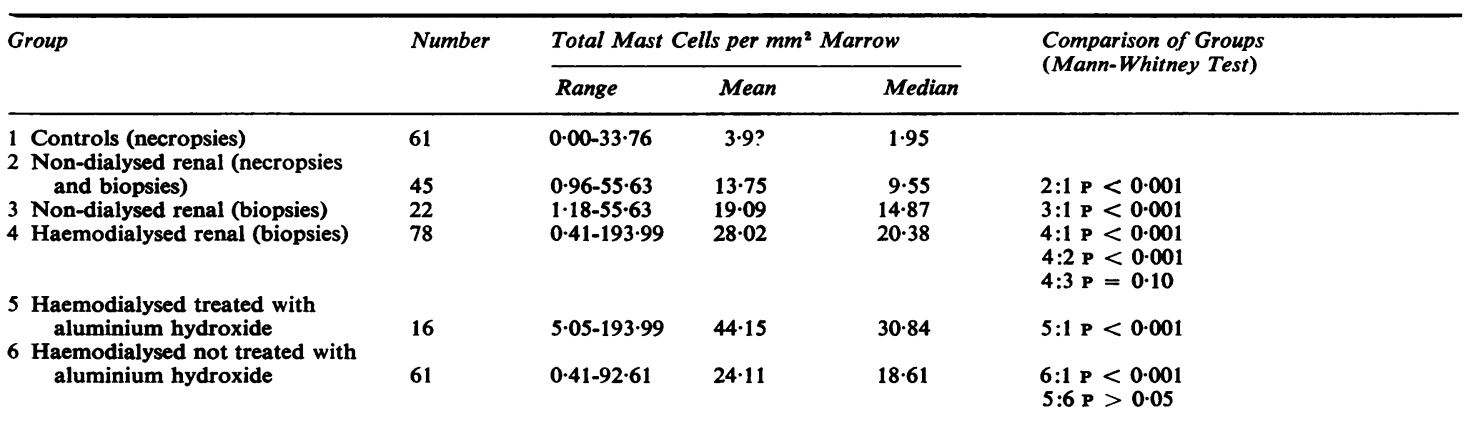

Table II Comparison of marrow mast cell numbers in 61 controls, 45 patients with chronic renal failure, and 78 patients with chronic renal failure treated by haemodialysis 


\begin{tabular}{lcc}
\hline Correlation & $\begin{array}{l}\text { Correlation } \\
\text { Coefficient }\end{array}$ & $\mathrm{P}$ \\
\hline LogMC/HDt & 0.303 & $<0.01$ \\
LogMC/TB & 0.167 & $>0.10$ \\
LogMC/MB & $\mathbf{0 . 0 9 3}$ & $>0.10$ \\
LogMC/O & $\mathbf{0 . 2 9 2}$ & $<0.01$ \\
LogMC/\% MIN & $-\mathbf{0 . 2 6 4}$ & $<0.05$ \\
TB/HDt & 0.236 & $<0.05$ \\
MB/HDt & 0.084 & $>0.10$ \\
O/HDt & 0.458 & $<0.001$ \\
$\%$ MIN/HDt & -0.453 & $<0.001$ \\
\hline
\end{tabular}

Table III Correlations between marrow mast cell numbers, mineralization status of bone, and duration of haemodialysis.

Abbreviations as in table $\mathbf{I}$.

these patients are given in table VII and an analysis of the results in table VIII.

It will be seen that in 15 of the 20 patients there was resolution or improvement of hyperparathyroidism with a significant reduction in the severity of osteitis fibrosa (fig 4) and numbers of osteoclasts (table VIII). This was accompanied by a fall in the

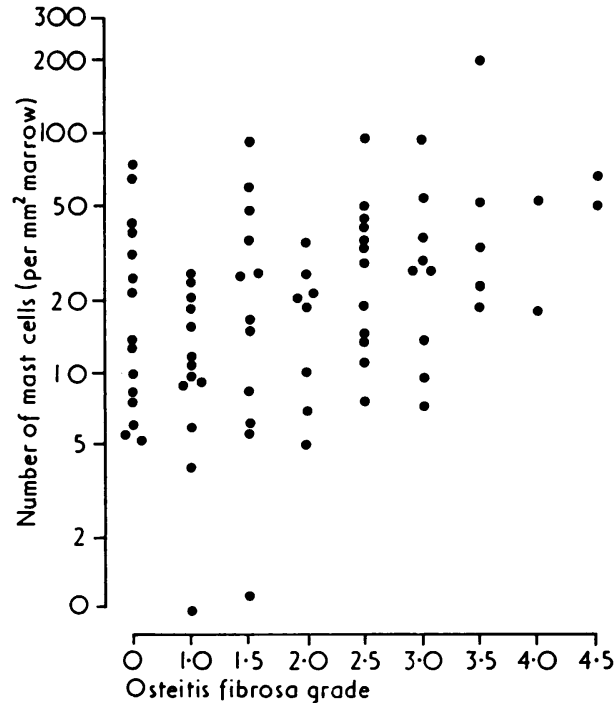

Fig 3 Geometric plot of marrow mast cell numbers for each grade of severity of osteitis fibrosa.

\begin{tabular}{|c|c|c|c|c|c|}
\hline \multirow{2}{*}{$\frac{\text { Correlation }}{\text { LogMC/HDt }}$} & \multicolumn{2}{|c|}{ Correlation Coefficient and $P$ Value } & \multicolumn{3}{|c|}{ Partial Correlation Coefficient and P Value } \\
\hline & $0 \cdot 303$ & $<0.01$ & $\begin{array}{l}\text { Excluding \% MIN } \\
\text { Excluding O }\end{array}$ & $\begin{array}{l}0.213 \\
0.199\end{array}$ & $\begin{array}{l}>0.05 \\
>0.05\end{array}$ \\
\hline $\begin{array}{l}\operatorname{LogMC} / \% \mathrm{MIN} \\
\% \mathrm{MIN} / \mathrm{HDt} \\
\text { LogMCO } \\
\text { O/HDt }\end{array}$ & $\begin{array}{r}-0.264 \\
-0.453 \\
0.292 \\
0.458\end{array}$ & $\begin{array}{l}<0.05 \\
<0.001 \\
<0.01 \\
<0.001\end{array}$ & $\begin{array}{l}\text { Excluding HDt } \\
\text { Excluding LogMC } \\
\text { Excluding HDt } \\
\text { Excluding LogMC }\end{array}$ & $\begin{array}{r}-0.135 \\
-0.406 \\
0.180 \\
0.463\end{array}$ & $\begin{array}{l}>0.10 \\
<0.001 \\
>0.10 \\
<0.001\end{array}$ \\
\hline
\end{tabular}

Table IV Correlation and partial correlation coefficients of relationships between log numbers of marrow mast cells, duration of haemodialysis, and bone mineralization status

Abbreviations as in table I

\begin{tabular}{|c|c|c|c|c|c|c|}
\hline \multirow[t]{2}{*}{ Case } & \multicolumn{3}{|c|}{ Marrow Mast Cells per $\mathrm{mm}^{2}$} & \multicolumn{3}{|c|}{ Duration of Haemodialysis ${ }^{2}$ (months) } \\
\hline & Biopsy 1 & Biopsy 2 & Difference & Biopsy 1 & Biopsy 2 & Difference \\
\hline $\begin{array}{l}25 \\
26 \\
36 \\
38 \\
46 \\
51 \\
61 \\
65 \\
71\end{array}$ & $\begin{array}{c}9 \cdot 15 \\
5 \cdot 39 \\
22 \cdot 70 \\
1 \cdot 32 \\
15 \cdot 06 \\
0 \\
0.31 \\
2 \cdot 92 \\
3 \cdot 57\end{array}$ & $\begin{array}{r}59 \cdot 36 \\
48 \cdot 18 \\
16 \cdot 54 \\
24 \cdot 51 \\
34 \cdot 76 \\
6 \cdot 06 \\
28 \cdot 74 \\
30 \cdot 94 \\
8 \cdot 31\end{array}$ & $\begin{array}{r}50.21 \\
42.79 \\
-\quad 6.16 \\
23.19 \\
19.70 \\
6.06 \\
28.43 \\
28.02 \\
4.74\end{array}$ & $\begin{array}{cl}-\quad 1.5 \\
& 0.5 \\
-\quad 3 \\
-\quad 1 \\
3 \\
1.5 \\
28 \\
1 \\
24\end{array}$ & $\begin{array}{l}10 \\
11 \\
14 \\
16 \\
22 \\
31 \\
41 \\
50 \\
58\end{array}$ & $\begin{array}{l}11 \cdot 5 \\
10 \cdot 5 \\
17 \\
17 \\
19 \\
29 \cdot 5 \\
13 \\
49 \\
34\end{array}$ \\
\hline $\begin{array}{l}1^{1} \\
16 \\
17 \\
40 \\
52 \\
70 \\
75\end{array}$ & $\begin{array}{l}20 \cdot 51 \\
15 \cdot 51 \\
32 \cdot 71 \\
18 \cdot 61 \\
21 \cdot 13 \\
35.06 \\
41 \cdot 84\end{array}$ & $\begin{array}{r}8 \cdot 13 \\
29 \cdot 20 \\
14 \cdot 93 \\
22 \cdot 36 \\
22 \cdot 00 \\
34 \cdot 79 \\
64 \cdot 35\end{array}$ & $\begin{array}{r}12.38 \\
13.69 \\
-17.78 \\
3.75 \\
0.87 \\
-\quad 0.27 \\
22.51\end{array}$ & $\begin{array}{c}0.25 \\
-\quad 2 \\
6 \\
18 \\
31 \\
55 \\
61\end{array}$ & $\begin{array}{r}10 \\
5 \\
22 \\
25 \\
37 \\
61 \\
67\end{array}$ & $\begin{array}{c}9 \cdot 75 \\
7 \\
16 \\
7 \\
6 \\
6 \\
6\end{array}$ \\
\hline
\end{tabular}

Table V Change in marrow mast cell numbers in 16 patients developing osteomalacia between first and second bone biopsies

${ }^{1}$ The last seven patients in the first column developed osteomalacia while being treated with oral aluminium hydroxide.

${ }^{2}$ Negative sign in 'biopsy 1 ' column indicates the first biopsy was obtained the stated number of months before haemodialysis and the 'difference column refers to the total time between biopsies. 


\begin{tabular}{|c|c|c|c|c|c|c|c|c|c|c|}
\hline \multirow{2}{*}{$\begin{array}{l}\text { Number of } \\
\text { Cases }\end{array}$} & \multirow{2}{*}{$\begin{array}{l}\text { Mast Cells } \\
\text { per } \mathrm{mm}^{2} \\
\text { Mean } \pm S E\end{array}$} & \multirow{2}{*}{$\begin{array}{l}\text { Osteitis } \\
\text { Fibrosa } \\
\text { Grade }\end{array}$} & \multicolumn{8}{|c|}{ Osteitis Fibrosa Grade } \\
\hline & & & 0 & 1 & $1 \cdot 5$ & 2 & $2 \cdot 5$ & 3 & $3 \cdot 5$ & 4 \\
\hline 15 & $1.22 \pm 0.10$ & 0 & - & & & & & & & \\
\hline 13 & $0.95 \pm 0.13$ & 1 & 1.64 & & & & & & & \\
\hline 12 & $1.30 \pm 0.18$ & 1.5 & 0.42 & 1.61 & & & & & & \\
\hline 8 & $1.17 \pm 0.11$ & 2 & 0.33 & $1 \cdot 16$ & 0.58 & & & & & \\
\hline 12 & $1.41 \pm 0.09$ & $2 \cdot 5$ & $1 \cdot 31$ & $2 \cdot 79 * *$ & 0.51 & 1.66 & & & & \\
\hline 9 & $1.39 \pm 0.12$ & 3 & 1.05 & $2 \cdot 36^{*}$ & 0.38 & $1 \cdot 38$ & $0 \cdot 10$ & & & \\
\hline 5 & $1.62 \pm 0.18$ & $3 \cdot 5$ & 1.96 & $2 \cdot 80^{* *}$ & 1.06 & $2 \cdot 33^{*}$ & $1 \cdot 19$ & $1 \cdot 12$ & & \\
\hline 2 & $1.48 \pm 0.23$ & 4 & 0.88 & $1 \cdot 50$ & 0.39 & $1 \cdot 29$ & 0.30 & 0.32 & 0.44 & \\
\hline 2 & $1.75 \pm 0.06$ & $4 \cdot 5$ & $1 \cdot 83$ & $2 \cdot 32^{*}$ & 0.99 & $2 \cdot 60 *$ & 1.47 & $1 \cdot 36$ & 0.41 & $1 \cdot 11$ \\
\hline
\end{tabular}

Table VI Table of geometric means. Relationship between log marrow mast cell numbers and grades of severity of osteitis fibrosa

* and ** refer to significant differences between grades with $\mathrm{P}<0.05$ and $<0.02$, respectively.

serum parathormone (Hill et al, 1975). In the remaining five patients the degree of hyperparathyroidism remained unchanged (3) or worsened (2). The number of mast cells bears no consistent relationship to these changes in osteitis fibrosa and there is no significant reduction in the number of total marrow or cellular marrow mast cells in the 15 patients showing improvement in osteitis fibrosa after aluminium hydroxide.

One of the undesired effects of this form of treatment is the tendency for it to increase the severity of osteomalacia present or be associated with the development of osteomalacia (Baker et al, 1974; Hill et al, 1975). Thus seven of the 20 patients in the present series developed osteomalacia, and there is an overall significant increase in the amount of osteoid between the pre- and post-treatment biopsies (table VIII). This provides the opportunity to ascertain whether or not there is any relationship between mast cell numbers and worsening or development of osteomalacia. Examination of the data shows no apparent relationship between mast cells and the development of osteomalacia, some patients showing a rise, some a fall, and some no change in mast cell numbers.

It is concluded that changes in the severity of osteitis fibrosa and in the bone mineralization brought about by aluminium hydroxide are not accompanied by any consistent change in the number of marrow mast cells.

\section{EFFECT OF PARATHYROIDECTOMY}

Serial bone biopsies were studied in four patients before and after parathyroidectomy and the results are summarized in table IX.

It is difficult to draw any firm conclusions regarding any possible relationship between the number of marrow mast cells and hyperparathyroidism in these patients. Thus although there is invariably a reduction in the severity of the osteitis fibrosa after removal of hyperplastic parathyroid glands there is no consistent corresponding fall in the number of marrow mast cells. In only one instance (case 35 ) is there any sustained fall in mast cell numbers parallel to the reduction in osteitis fibrosa. Changes in the mineralization status also occur in these patients and serve further to complicate interpretation if indeed it is eventually shown that there is a relationship between mast cells and osteomalacia.

EFFECT OF TREATMENT WITH 1, 25 DIHYDROXYCHOLECALCIFEROL $(1,25$ $\left.(\mathrm{OH})_{2} \mathrm{D}_{3}\right)$ AND $1 \alpha$ HYDROXYCHOLECALCIFEROL $\left(1-\alpha-\mathrm{OH}-\mathrm{D}_{3}\right)$

It has recently been shown that administration of $1,25-(\mathrm{OH})_{2} \mathrm{D}_{3}$ reduces the severity of osteitis fibrosa, lowers serum parathormone, and produces improvement in the mineralization of bone in haemodialysed patients (Pierides et al, 1976b). We were therefore interested to ascertain whether there was any concurrent change in marrow mast cell numbers.

Five patients treated by 1 to $1.5 \mu \mathrm{g}$ of 1,25 $(\mathrm{OH})_{2} \mathrm{D}_{3}$ daily for 6-8 months all show lessening of the severity of the osteitis fibrosa with significant reduction in the number of osteoclasts $(P<0.001)$ but the marrow mast cell response is variable-increasing in three, falling in one, and remaining unchanged in the fifth patient (table $\mathrm{X}$ ), there being no significant change overall $(P>0 \cdot 10)$. Osteomalacia improved in one, resolved in three, and remained about the same in the fifth patient. There is an overall significant reduction in the amount of osteoid $(P<0.05)$.

Four patients were treated by $1-3 \mu \mathrm{g}$ of $1-\alpha-\mathrm{OH}-\mathrm{D}_{3}$ daily for 6-8 months (table $X$ ). In two patients both the osteomalacia and osteitis fibrosa improved but there was only a slight fall in marrow mast cell numbers in one of these, and in the other there was an increase. In the two patients with no significant 


\begin{tabular}{|c|c|c|c|c|c|c|c|c|c|c|}
\hline \multirow[t]{3}{*}{ Case } & \multirow{2}{*}{\multicolumn{2}{|c|}{$\begin{array}{l}\text { Number of Mast Cells } \\
\text { per } \mathrm{mm}^{2}\end{array}$}} & \multirow{3}{*}{$\begin{array}{l}\text { Number } \\
\text { Osteoclasts } \\
\text { per } \mathrm{mm}^{2}\end{array}$} & \multirow{3}{*}{$\begin{array}{l}\text { Severity of } \\
\text { Osteitis Fibrosa } \\
\text { (grade 0-5) }\end{array}$} & \multicolumn{6}{|c|}{ Mineralization Data } \\
\hline & & & & & $T B$ & $M B$ & $O$ & $\% M I N$ & $\boldsymbol{L}$ & $O M$ \\
\hline & $\begin{array}{l}\text { Total } \\
\text { Marrow }\end{array}$ & $\begin{array}{l}\text { Fatty or } \\
\text { Cellular } \\
\text { Marrow }\end{array}$ & & & & & & & & $(+o r-)$ \\
\hline 1 & $\begin{array}{r}20 \cdot 51 \\
8 \cdot 13\end{array}$ & $\begin{array}{r}17 \cdot 10 \\
8 \cdot 12\end{array}$ & $\begin{array}{l}0 \cdot 34 \\
2 \cdot 25\end{array}$ & $\begin{array}{l}2 \\
2 \cdot 5\end{array}$ & $\begin{array}{l}15 \cdot 2 \\
37 \cdot 1\end{array}$ & $\begin{array}{l}14 \cdot 9 \\
34 \cdot 8\end{array}$ & $\begin{array}{l}0 \cdot 32 \\
2 \cdot 37\end{array}$ & $\begin{array}{l}97 \cdot 9 \\
93 \cdot 6\end{array}$ & $\begin{array}{l}2 \\
6\end{array}$ & $\bar{t}$ \\
\hline 14 & $\begin{array}{l}25 \cdot 07 \\
51 \cdot 28\end{array}$ & $\begin{array}{l}24 \cdot 83 \\
47 \cdot 32\end{array}$ & $\begin{array}{l}0.61 \\
1 \cdot 01\end{array}$ & $\begin{array}{l}2 \\
2\end{array}$ & $\begin{array}{l}31 \cdot 1 \\
25 \cdot 6\end{array}$ & $\begin{array}{l}27 \cdot 3 \\
21 \cdot 2\end{array}$ & $\begin{array}{l}3 \cdot 71 \\
4 \cdot 35\end{array}$ & $\begin{array}{l}88 \cdot 1 \\
82 \cdot 9\end{array}$ & 5 & $\begin{array}{l}+ \\
+\end{array}$ \\
\hline 16 & $\begin{array}{l}15 \cdot 51 \\
29 \cdot 20\end{array}$ & $\begin{array}{l}13 \cdot 74 \\
18 \cdot 17\end{array}$ & $\begin{array}{l}3 \cdot 15 \\
3 \cdot 61\end{array}$ & $\begin{array}{l}4 \\
3\end{array}$ & $\begin{array}{l}24 \cdot 8 \\
25 \cdot 7\end{array}$ & $\begin{array}{l}23 \cdot 2 \\
21 \cdot 3\end{array}$ & $\begin{array}{l}1 \cdot 51 \\
4 \cdot 44\end{array}$ & $\begin{array}{l}93 \cdot 9 \\
82 \cdot 7\end{array}$ & $\begin{array}{l}3 \\
6\end{array}$ & $\overline{+}$ \\
\hline 17 & $\begin{array}{l}32 \cdot 71 \\
14 \cdot 93\end{array}$ & $\begin{array}{l}31 \cdot 02 \\
14 \cdot 93\end{array}$ & $\begin{array}{l}2 \cdot 18 \\
0 \cdot 31\end{array}$ & $\begin{array}{l}3 \\
1 \cdot 5\end{array}$ & $\begin{array}{l}259 \\
27 \cdot 1\end{array}$ & $\begin{array}{l}24 \cdot 0 \\
18 \cdot 6\end{array}$ & $\begin{array}{l}1 \cdot 88 \\
8 \cdot 55\end{array}$ & $\begin{array}{l}92 \cdot 7 \\
68 \cdot 5\end{array}$ & $\begin{array}{l}4 \\
9\end{array}$ & $\overline{+}$ \\
\hline $22^{1}$ & $\begin{array}{c}10.71 \\
26.30\end{array}$ & $\begin{array}{r}9 \cdot 98 \\
26 \cdot 30\end{array}$ & $\begin{array}{l}1 \cdot 37 \\
0\end{array}$ & $\begin{array}{l}2 \cdot 5 \\
0\end{array}$ & $\begin{array}{l}32 \cdot 2 \\
20 \cdot 6\end{array}$ & $\begin{array}{l}29 \cdot 0 \\
18 \cdot 1\end{array}$ & $\begin{array}{l}3 \cdot 21 \\
2 \cdot 53\end{array}$ & $\begin{array}{l}90 \cdot 0 \\
87 \cdot 8\end{array}$ & $\begin{array}{l}5 \\
5\end{array}$ & $\begin{array}{l}+ \\
+\end{array}$ \\
\hline 27 & $\begin{array}{r}6.79 \\
42.91\end{array}$ & $\begin{array}{r}5 \cdot 34 \\
42 \cdot 91\end{array}$ & $\begin{array}{l}0.61 \\
0.25\end{array}$ & $\begin{array}{l}2 \\
0\end{array}$ & $\begin{array}{l}22 \cdot 1 \\
13 \cdot 7\end{array}$ & $\begin{array}{l}19 \cdot 4 \\
12 \cdot 2\end{array}$ & $\begin{array}{l}2 \cdot 74 \\
1 \cdot 46\end{array}$ & $\begin{array}{l}87 \cdot 6 \\
89 \cdot 3\end{array}$ & $\begin{array}{l}5 \\
5\end{array}$ & $\begin{array}{l}+ \\
+\end{array}$ \\
\hline 29 & $\begin{array}{l}9 \cdot 75 \\
3 \cdot 18\end{array}$ & $\begin{array}{l}9 \cdot 68 \\
3 \cdot 18\end{array}$ & $\begin{array}{l}1.05 \\
0.05\end{array}$ & $\begin{array}{l}2 \\
0\end{array}$ & $\begin{array}{l}25 \cdot 2 \\
36 \cdot 5\end{array}$ & $\begin{array}{l}21 \cdot 8 \\
30 \cdot 8\end{array}$ & $\begin{array}{l}3 \cdot 43 \\
5 \cdot 72\end{array}$ & $\begin{array}{l}84 \cdot 6 \\
84 \cdot 3\end{array}$ & $\begin{array}{l}6 \\
5\end{array}$ & + \\
\hline 32 & $\begin{array}{l}7 \cdot 15 \\
4 \cdot 17\end{array}$ & $\begin{array}{l}7 \cdot 14 \\
4 \cdot 10\end{array}$ & $\begin{array}{l}1.95 \\
0.38\end{array}$ & $\begin{array}{l}3 \\
2\end{array}$ & $\begin{array}{l}28 \cdot 2 \\
23 \cdot 6\end{array}$ & $\begin{array}{l}27 \cdot 3 \\
22 \cdot 0\end{array}$ & $\begin{array}{l}0.88 \\
1 \cdot 59\end{array}$ & $\begin{array}{l}96.9 \\
93.2\end{array}$ & $\begin{array}{l}2 \\
4\end{array}$ & - \\
\hline 33 & $\begin{array}{r}18 \cdot 66 \\
6 \cdot 13\end{array}$ & $\begin{array}{r}19 \cdot 28 \\
6 \cdot 13\end{array}$ & $\begin{array}{l}8 \cdot 20 \\
0 \cdot 12\end{array}$ & $\begin{array}{l}3 \cdot 5 \\
0\end{array}$ & $\begin{array}{l}22 \cdot 2 \\
29 \cdot 2\end{array}$ & $\begin{array}{l}18 \cdot 6 \\
25 \cdot 7\end{array}$ & $\begin{array}{l}3 \cdot 52 \\
3 \cdot 49\end{array}$ & $\begin{array}{l}84 \cdot 1 \\
88 \cdot 0\end{array}$ & $\begin{array}{l}5 \\
5\end{array}$ & $\begin{array}{l}+ \\
+\end{array}$ \\
\hline 40 & $\begin{array}{l}18 \cdot 61 \\
22 \cdot 36\end{array}$ & $\begin{array}{l}18 \cdot 39 \\
21 \cdot 39\end{array}$ & $\begin{array}{l}1.05 \\
0.07\end{array}$ & $\begin{array}{l}2 \\
0\end{array}$ & $\begin{array}{l}15 \cdot 3 \\
19 \cdot 5\end{array}$ & $\begin{array}{l}14 \cdot 6 \\
17 \cdot 9\end{array}$ & $\begin{array}{l}0.70 \\
1.57\end{array}$ & $\begin{array}{l}95.5 \\
91.9\end{array}$ & $\begin{array}{l}2 \\
5\end{array}$ & $\overline{+}$ \\
\hline 43 & $\begin{array}{l}92 \cdot 43 \\
72 \cdot 83\end{array}$ & $\begin{array}{l}64 \cdot 83 \\
71 \cdot 48\end{array}$ & $\begin{array}{l}2 \cdot 49 \\
0 \cdot 27\end{array}$ & $\begin{array}{l}2 \cdot 5 \\
1 \cdot 5\end{array}$ & $\begin{array}{l}25 \cdot 0 \\
25 \cdot 4\end{array}$ & $\begin{array}{l}23 \cdot 1 \\
24 \cdot 4\end{array}$ & $\begin{array}{l}1.96 \\
0.98\end{array}$ & $\begin{array}{l}92 \cdot 2 \\
96 \cdot 1\end{array}$ & $\begin{array}{l}5 \\
4\end{array}$ & $\begin{array}{l}+ \\
-\end{array}$ \\
\hline 52 & $\begin{array}{l}21 \cdot 13 \\
22 \cdot 00\end{array}$ & $\begin{array}{l}16 \cdot 29 \\
21 \cdot 75\end{array}$ & $\begin{array}{l}3.31 \\
0.08\end{array}$ & $\begin{array}{l}2 \cdot 0 \\
0\end{array}$ & $\begin{array}{l}27 \cdot 0 \\
23 \cdot 6\end{array}$ & $\begin{array}{l}26 \cdot 1 \\
20 \cdot 6\end{array}$ & $\begin{array}{l}0.95 \\
2.96\end{array}$ & $\begin{array}{l}96 \cdot 5 \\
87 \cdot 4\end{array}$ & $\begin{array}{l}3 \\
7\end{array}$ & $\overline{+}$ \\
\hline $63^{1}$ & $\begin{array}{l}7 \cdot 44 \\
7 \cdot 79\end{array}$ & $\begin{array}{l}5.08 \\
7 \cdot 00\end{array}$ & $\begin{array}{l}0.85 \\
0.64\end{array}$ & $\begin{array}{l}2 \cdot 5 \\
2\end{array}$ & $\begin{array}{l}26 \cdot 2 \\
15 \cdot 1\end{array}$ & $\begin{array}{l}23 \cdot 8 \\
14 \cdot 5\end{array}$ & $\begin{array}{l}2.44 \\
1.02\end{array}$ & $\begin{array}{l}90.7 \\
93.4\end{array}$ & $\begin{array}{l}5 \\
4\end{array}$ & $\begin{array}{l}+ \\
-\end{array}$ \\
\hline 64 & $\begin{array}{l}13.60 \\
14.90\end{array}$ & $\begin{array}{r}10 \cdot 50 \\
9 \cdot 23\end{array}$ & $\begin{array}{l}7 \cdot 21 \\
0 \cdot 72\end{array}$ & $\begin{array}{l}3 \cdot 5 \\
2 \cdot 5\end{array}$ & $\begin{array}{l}41 \cdot 2 \\
29 \cdot 1\end{array}$ & $\begin{array}{l}35 \cdot 9 \\
22 \cdot 4\end{array}$ & $\begin{array}{l}5 \cdot 34 \\
6 \cdot 68\end{array}$ & $\begin{array}{l}87 \cdot 1 \\
77 \cdot 0\end{array}$ & $\begin{array}{l}6 \\
8\end{array}$ & $\begin{array}{l}+ \\
+\end{array}$ \\
\hline 67 & $\begin{array}{l}40 \cdot 60 \\
46 \cdot 23\end{array}$ & $\begin{array}{c}37 \cdot 29 \\
39 \cdot 63\end{array}$ & $\begin{array}{l}0.15 \\
1.62\end{array}$ & $\begin{array}{l}2 \cdot 5 \\
2 \cdot 5\end{array}$ & $\begin{array}{l}26 \cdot 8 \\
30 \cdot 3\end{array}$ & $\begin{array}{l}23 \cdot 1 \\
20 \cdot 8\end{array}$ & $\begin{array}{l}3 \cdot 74 \\
9 \cdot 46\end{array}$ & $\begin{array}{l}86 \cdot 0 \\
68 \cdot 7\end{array}$ & $\begin{array}{l}6 \\
7\end{array}$ & $\begin{array}{l}+ \\
+\end{array}$ \\
\hline 68 & $\begin{array}{l}92 \cdot 61 \\
34 \cdot 87\end{array}$ & $\begin{array}{l}91 \cdot 56 \\
36 \cdot 15\end{array}$ & $\begin{array}{l}6 \cdot 50 \\
5 \cdot 45\end{array}$ & $\begin{array}{l}3 \\
3 \cdot 5\end{array}$ & $\begin{array}{l}28 \cdot 8 \\
39 \cdot 7\end{array}$ & $\begin{array}{l}26 \cdot 0 \\
36 \cdot 0\end{array}$ & $\begin{array}{l}2 \cdot 79 \\
3 \cdot 74\end{array}$ & $\begin{array}{l}90 \cdot 3 \\
90 \cdot 6\end{array}$ & $\begin{array}{l}3 \\
4\end{array}$ & $\overline{-}$ \\
\hline 70 & $\begin{array}{l}35 \cdot 06 \\
34 \cdot 79\end{array}$ & $\begin{array}{l}22 \cdot 56 \\
34 \cdot 54\end{array}$ & $\begin{array}{l}1 \cdot 18 \\
0 \cdot 05\end{array}$ & $\begin{array}{l}2 \cdot 5 \\
1\end{array}$ & $\begin{array}{l}26 \cdot 5 \\
17 \cdot 2\end{array}$ & $\begin{array}{l}25 \cdot 4 \\
13 \cdot 0\end{array}$ & $\begin{array}{l}1 \cdot 11 \\
4 \cdot 21\end{array}$ & $\begin{array}{l}95 \cdot 8 \\
75 \cdot 5\end{array}$ & $\begin{array}{l}2 \\
9\end{array}$ & $\overline{+}$ \\
\hline $72^{2}$ & $\begin{array}{l}46.44 \\
51 \cdot 54\end{array}$ & $\begin{array}{l}47 \cdot 18 \\
59 \cdot 98\end{array}$ & $\begin{array}{l}8.61 \\
6.07\end{array}$ & $\begin{array}{l}4 \\
2\end{array}$ & $\overline{37 \cdot 0}$ & $\overline{27 \cdot 6}$ & $\overline{9} \cdot 41$ & $\overline{74 \cdot 5}$ & $\overline{6}$ & $\overline{+}$ \\
\hline 75 & $\begin{array}{l}41 \cdot 84 \\
64 \cdot 35\end{array}$ & $\begin{array}{l}37 \cdot 32 \\
18 \cdot 25\end{array}$ & $\begin{array}{l}3 \cdot 79 \\
9 \cdot 68\end{array}$ & $\begin{array}{l}4 \cdot 5 \\
4 \cdot 5\end{array}$ & $\begin{array}{l}40 \cdot 9 \\
47 \cdot 4\end{array}$ & $\begin{array}{l}33 \cdot 0 \\
36 \cdot 1\end{array}$ & $\begin{array}{r}7 \cdot 91 \\
11 \cdot 22\end{array}$ & $\begin{array}{l}80 \cdot 7 \\
76 \cdot 3\end{array}$ & $\begin{array}{l}3 \\
6\end{array}$ & $\overline{+}$ \\
\hline 77 & $\begin{array}{l}60 \cdot 71 \\
45 \cdot 00\end{array}$ & $\begin{array}{l}42 \cdot 20 \\
45 \cdot 00\end{array}$ & $\begin{array}{l}4 \cdot 95 \\
0 \cdot 37\end{array}$ & $\begin{array}{l}3 \cdot 5 \\
2\end{array}$ & $\begin{array}{l}36 \cdot 0 \\
31 \cdot 4\end{array}$ & $\begin{array}{l}28 \cdot 6 \\
22 \cdot 8\end{array}$ & $\begin{array}{l}7 \cdot 36 \\
8 \cdot 58\end{array}$ & $\begin{array}{l}79 \cdot 5 \\
72 \cdot 7\end{array}$ & $\begin{array}{l}6 \\
7\end{array}$ & $\begin{array}{l}+ \\
+\end{array}$ \\
\hline
\end{tabular}

Table VII Details of numbers of mast cells and corresponding quantitative data of hyperparathyroidism and bone mineralization status in 20 haemodialysed patients treated by oral calcium carbonate and aluminium hydroxide

(For further details of these patients see table I and Hill et al, 1975.)

${ }^{1}$ Renal transplant after 2-3 months treatment.

${ }^{2}$ No undecalcified sections available for first biopsy. Abbreviations as in previous tables.

improvement in osteitis fibrosa or osteomalacia the numbers of marrow mast cells were increased in one and reduced in the other. Overall there is no significant change in mast cells, osteoid or osteoclasts $(P>0 \cdot 10)$.

There is thus no clear relationship between marrow mast cell numbers and the changes in the severity of osteomalacia or osteitis fibrosa in these nine patients treated by vitamin $\mathbf{D}$ metabolites.

MARROW MAST CELLS IN NON-RENAL OSTEOMALACIA

To ascertain whether or not increased marrow mast cells are solely characteristic of chronic renal failure we have examined bone biopsies from 10 patients with osteomalacia resulting from miscellaneous causes in the absence of chronic renal failure. The results of the mast cell counts and details of the quantitative bone histology are summarized in table XI. There is an increase in the number of marrow mast cells in several of these patients. The range is 1.32 to 73.99 , arithmetic mean 21.25 , and median 11.99 mast cells per $\mathrm{mm}^{2}$ marrow. Comparison! of the group as a whole with the control group by the Mann-Whitney test confirms that there is a significant increase in mast cell numbers in the bone mar- 


\begin{tabular}{|c|c|c|c|c|c|c|c|c|c|c|c|c|c|c|c|c|c|}
\hline \multirow[t]{2}{*}{ Group } & \multicolumn{4}{|c|}{ Osteoclasts per $\mathrm{mm}^{2}$} & \multicolumn{5}{|c|}{$\begin{array}{l}\text { Cellular Marrow Mast } \\
\text { Cells per } \mathrm{mm}^{2}\end{array}$} & \multicolumn{4}{|c|}{$\begin{array}{l}\text { Total Marrow Mast Cells } \\
\text { per } \mathrm{mm}^{2}\end{array}$} & \multicolumn{4}{|c|}{$\begin{array}{l}\text { Osteoid percent Measured } \\
\text { Area }\end{array}$} \\
\hline & $n$ & $\bar{d}$ & $s \vec{d}$ & $P$ & $n$ & $\bar{d}$ & & $\overline{s d}$ & $P$ & $n$ & $\bar{d}$ & $s \bar{d}$ & $P$ & $n$ & $\bar{d}$ & $s \bar{d}$ & $P$ \\
\hline All cases & 20 & $-1 \cdot 33$ & 0.67 & $>0.05$ & 20 & - & $2 \cdot 79$ & $5 \cdot 34$ & $>0.10$ & 20 & -0.72 & $4 \cdot 48$ & $>0 \cdot 10$ & 19 & $1 \cdot 55$ & 0.50 & $<0.005$ \\
\hline $\begin{array}{l}\text { Non-responders } \\
\text { (osteitis fibrosa } \\
\text { unchanged or } \\
\text { worse) }\end{array}$ & 5 & $1 \cdot 72$ & $1 \cdot 16$ & $>0.10$ & 5 & - & $11 \cdot 73$ & 12.92 & $>0.10$ & 5 & -3.15 & $15 \cdot 27$ & $>0.10$ & 5 & $2 \cdot 53$ & 0.92 & $>0.05$ \\
\hline $\begin{array}{l}\text { Responders } \\
\text { (osteitis fibrosa } \\
\text { improved or } \\
\text { resolved) }\end{array}$ & 15 & $-3 \cdot 18$ & 0.61 & $<0.01$ & 15 & & $4 \cdot 19$ & $3 \cdot 32$ & $>0 \cdot 10$ & 15 & 0.07 & $3 \cdot 74$ & $>0.10$ & 14 & $1 \cdot 20$ & 0.58 & $>0.05$ \\
\hline $\begin{array}{l}\text { Comparison me } \\
\text { differences for } \\
\text { non-responders } \\
\text { and responders }\end{array}$ & & & $\mathbf{P}<$ & & & & & $\mathbf{P}>0$ & & & & $\mathbf{P}>0$ & & & & $\mathbf{P}>0$ & \\
\hline
\end{tabular}

\section{Table VIII Differences between pre- and post-treatment bone biopsies}

Summary of statistical analyses related to table VII showing there is a significant fall in the number of osteoclasts in those patients with a reduction in severity of osteitis fibrosa after aluminium hydroxide therapy and no corresponding change in mast cell numbers. The amount of osteoid is also increased as a result of the treatment and this is significant when all cases are considered collectively.

$\mathrm{n}$, number of cases; $\overline{\mathrm{d}}$ and $\mathrm{s} \overline{\mathrm{d}}$, mean and standard error of differences between biopsies.

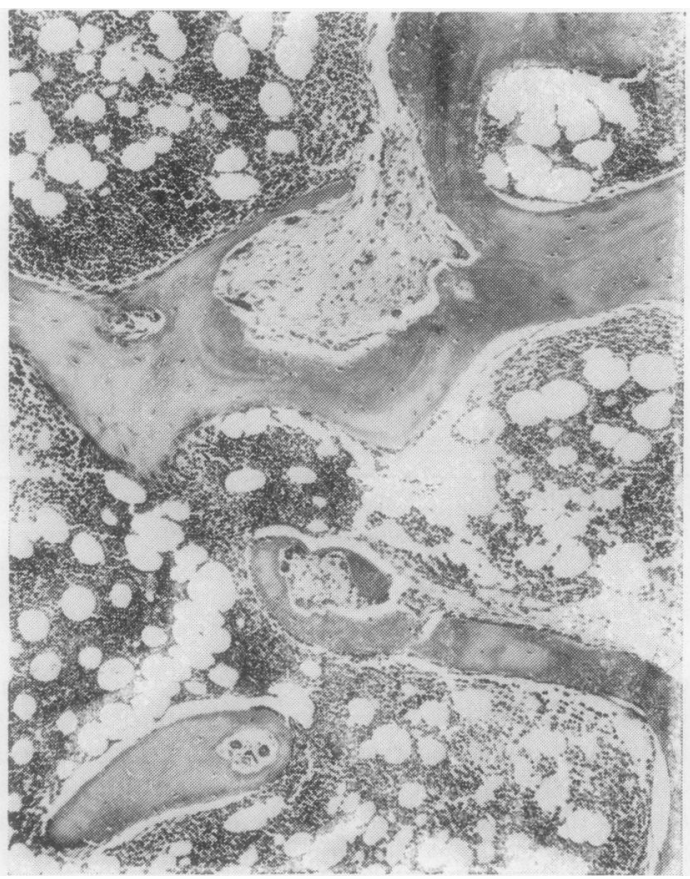

a

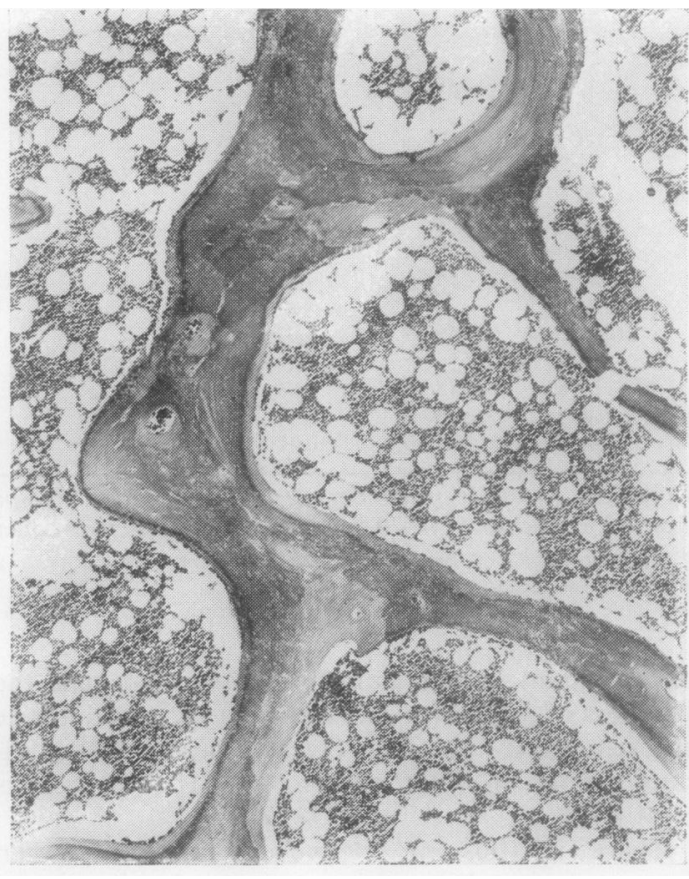

b

Fig 4 Case 33. Effect of oral aluminium hydroxide therapy on osteitis fibrosa in chronic renal failure.

(a) Pre-treatment iliac bone biopsy showing deep resorption of cancellous bone by osteoclasts and accompanying marrow fibrosis. (b) Post-treatment biopsy showing resolution of osteitis fibrosa with no active resorption or marrow fibrosis and pale staining newly formed bone filling in resorption lacunae. Decalcified, haematoxylin and eosin (a) $\times 70($ b $) \times 50$. 


\begin{tabular}{|c|c|c|c|c|c|c|c|c|c|c|}
\hline \multirow[t]{3}{*}{ Case } & \multirow{3}{*}{$\begin{array}{l}\text { Time of } \\
\text { Bone Biopsy } \\
\text { (mth) }\end{array}$} & \multirow{3}{*}{$\begin{array}{l}\text { Mast } \\
\text { Cel s } \\
\text { per } \mathrm{mm}^{2} \\
\text { Marrow }\end{array}$} & \multicolumn{5}{|c|}{ Mineralization Data } & \multicolumn{3}{|c|}{ Hyperparathyroidism Data } \\
\hline & & & \multirow{2}{*}{$T B$} & \multirow[t]{2}{*}{$M B$} & \multirow[t]{2}{*}{$O$} & \multirow[t]{2}{*}{$\% M I N$} & \multirow[t]{2}{*}{$O M$} & \multirow[t]{2}{*}{$O C L$} & \multirow[t]{2}{*}{$O F G$} & Parathyroids \\
\hline & & & & & & & & & & Histology \\
\hline $35(34 *)$ & $\begin{array}{l}14 \text { pre HD } \\
14 \text { HD } \\
20 \mathrm{HD}\end{array}$ & $\begin{array}{r}72 \cdot 54 \\
8 \cdot 65 \\
2 \cdot 41\end{array}$ & $\begin{array}{l}20 \cdot 5 \\
18 \cdot 6 \\
19 \cdot 8\end{array}$ & $\begin{array}{l}19 \cdot 9 \\
17 \cdot 1 \\
16 \cdot 8\end{array}$ & $\begin{array}{l}0.68 \\
1 \cdot 44 \\
2 \cdot 93\end{array}$ & $\begin{array}{l}96 \cdot 7 \\
92 \cdot 2 \\
85 \cdot 1\end{array}$ & $\begin{array}{l}- \\
-\end{array}$ & $\begin{array}{l}11 \cdot 11 \\
0 \\
0.05\end{array}$ & $\begin{array}{l}5 \\
1 \\
0\end{array}$ & $\begin{array}{l}4 \quad 4.620 \quad \text { Type IV } \\
\text { (removed on day of 1st bone } \\
\text { biopsy) }\end{array}$ \\
\hline $9\left(18^{*}\right)$ & $\begin{array}{l}7 \text { pre HD } \\
13 \mathrm{HD} \\
18 \mathrm{HD} \\
25 \mathrm{HD} \\
38 \mathrm{HD}\end{array}$ & $\begin{array}{l}25 \cdot 03 \\
21 \cdot 55 \\
23 \cdot 63 \\
15 \cdot 53 \\
24 \cdot 71\end{array}$ & $\begin{array}{l}19 \cdot 8 \\
23 \cdot 1 \\
22 \cdot 3 \\
18 \cdot 9 \\
21 \cdot 9\end{array}$ & $\begin{array}{l}18 \cdot 8 \\
20 \cdot 9 \\
21 \cdot 2 \\
17 \cdot 3 \\
20 \cdot 9\end{array}$ & $\begin{array}{l}1 \cdot 00 \\
2 \cdot 19 \\
1 \cdot 15 \\
1 \cdot 54 \\
1 \cdot 00\end{array}$ & $\begin{array}{l}95.0 \\
90.5 \\
94.9 \\
91 \cdot 8 \\
95.5\end{array}$ & $\begin{array}{l}- \\
+ \\
+ \\
+ \\
+\end{array}$ & $\begin{array}{l}5.00 \\
0 \\
0.04 \\
0 \cdot 10 \\
0.04\end{array}$ & $\begin{array}{l}3 \cdot 5 \\
0 \\
0 \\
0 \\
0\end{array}$ & $\begin{array}{l}4 \quad 2 \cdot 354 \quad \text { Type IV } \\
\text { (removed } 6 \mathrm{mth} \text { after 1st bone } \\
\text { biopsy) }\end{array}$ \\
\hline 80 & $\begin{array}{l}44 \mathrm{HD} \\
55 \mathrm{HD} \\
78 \mathrm{HD}\end{array}$ & $\begin{array}{r}17 \cdot 22 \\
10 \cdot 55 \\
9 \cdot 59\end{array}$ & $\begin{array}{l}52 \cdot 0 \\
56 \cdot 3 \\
38 \cdot 3\end{array}$ & $\begin{array}{l}40 \cdot 0 \\
40 \cdot 0 \\
37 \cdot 4\end{array}$ & $\begin{array}{r}12 \cdot 05 \\
16 \cdot 31 \\
0 \cdot 89\end{array}$ & $\begin{array}{l}76 \cdot 8 \\
71 \cdot 0 \\
97 \cdot 7\end{array}$ & $\begin{array}{l}+ \\
+ \\
-\end{array}$ & $\begin{array}{l}6 \cdot 07 \\
0 \cdot 77 \\
0 \cdot 17\end{array}$ & $\begin{array}{l}3 \\
1 \cdot 5 \\
0\end{array}$ & 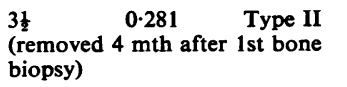 \\
\hline 81 & $\begin{array}{l}2 \text { pre HD } \\
12 \text { HD } \\
37 \text { HD }\end{array}$ & $\begin{array}{r}7 \cdot 87 \\
7 \cdot 80 \\
17 \cdot 61\end{array}$ & $\begin{array}{l}22 \cdot 2 \\
16 \cdot 4 \\
32 \cdot 7\end{array}$ & $\begin{array}{l}18 \cdot 2 \\
15 \cdot 6 \\
30 \cdot 5\end{array}$ & $\begin{array}{l}3 \cdot 94 \\
0 \cdot 82 \\
2 \cdot 28\end{array}$ & $\begin{array}{l}82 \cdot 2 \\
95 \cdot 0 \\
93 \cdot 0\end{array}$ & $\begin{array}{l}+ \\
-\end{array}$ & $\begin{array}{l}7 \cdot 70 \\
0 \cdot 01 \\
0 \cdot 87\end{array}$ & $\begin{array}{l}4 \\
1 \\
1 \cdot 5\end{array}$ & $\begin{array}{l}3 \frac{1}{2} \quad 1.846 \quad \text { Type IV } \\
\text { (removed } 16 \text { days after 1st bone } \\
\text { biopsy) }\end{array}$ \\
\hline
\end{tabular}

Table IX Details of total marrow mast cell numbers, mineralization of bone, and severity of hyperparathyroidism in four patients treated by parathyroidectomy

Starred numbers in brackets refer to case numbers in Ellis and Peart (1973).

OCL, number of osteoclasts per $\mathrm{mm}^{2}$; parathyroid histology refers to types II and IV of Gilmour (1947); other abbreviations as in table I.

\begin{tabular}{|c|c|c|c|c|c|c|c|c|c|c|}
\hline Case & Treatment & $\begin{array}{l}\text { Mast Cells } \\
\text { per } \mathrm{mm}^{2}\end{array}$ & $T B$ & $M B$ & $O$ & $\% M I N$ & $L$ & $O M$ & $O C L$ & $O F G$ \\
\hline 9 & $1,25-(\mathrm{OH})_{2} \mathrm{D}_{3}$ & $\begin{array}{r}20 \cdot 25 \\
6 \cdot 37\end{array}$ & $\begin{array}{l}17 \cdot 4 \\
13 \cdot 7\end{array}$ & $\begin{array}{l}15 \cdot 9 \\
12 \cdot 9\end{array}$ & $\begin{array}{l}1 \cdot 56 \\
0 \cdot 88\end{array}$ & $\begin{array}{l}91 \cdot 0 \\
93.6\end{array}$ & $\begin{array}{l}5 \\
4\end{array}$ & $\begin{array}{l}+ \\
-\end{array}$ & $\begin{array}{l}2 \cdot 49 \\
0 \cdot 12\end{array}$ & $\begin{array}{l}3 \cdot 5 \\
1\end{array}$ \\
\hline 29 & $1,25-(\mathrm{OH})_{2} \mathrm{D}_{3}$ & $\begin{array}{l}10 \cdot 16 \\
18 \cdot 01\end{array}$ & $\begin{array}{l}30 \cdot 6 \\
38 \cdot 3\end{array}$ & $\begin{array}{l}26 \cdot 5 \\
37 \cdot 5\end{array}$ & $\begin{array}{l}4.05 \\
0.78\end{array}$ & $\begin{array}{l}86 \cdot 7 \\
98 \cdot 0\end{array}$ & $\begin{array}{l}6 \\
4\end{array}$ & $\begin{array}{l}+ \\
-\end{array}$ & $\begin{array}{l}2 \cdot 73 \\
0 \cdot 04\end{array}$ & $\begin{array}{l}2 \\
0\end{array}$ \\
\hline 41 & $1,25-(\mathrm{OH})_{2} \mathrm{D}_{3}$ & $\begin{array}{l}21 \cdot 30 \\
56 \cdot 34\end{array}$ & $\begin{array}{l}24 \cdot 2 \\
15 \cdot 8\end{array}$ & $\begin{array}{l}19.0 \\
13.4\end{array}$ & $\begin{array}{l}5 \cdot 28 \\
2 \cdot 41\end{array}$ & $\begin{array}{l}78 \cdot 2 \\
84 \cdot 7\end{array}$ & $\begin{array}{l}9 \\
5\end{array}$ & $\begin{array}{l}+ \\
+\end{array}$ & $\begin{array}{l}1 \cdot 80 \\
0 \cdot 47\end{array}$ & $\begin{array}{l}2 \cdot 5 \\
1\end{array}$ \\
\hline 56 & $1,25-(\mathrm{OH})_{2} \mathrm{D}_{3}$ & $\begin{array}{l}193.99 \\
191.04\end{array}$ & $\begin{array}{l}36 \cdot 7 \\
28 \cdot 6\end{array}$ & $\begin{array}{l}30 \cdot 7 \\
27 \cdot 8\end{array}$ & $\begin{array}{l}6.04 \\
0.80\end{array}$ & $\begin{array}{l}83 \cdot 6 \\
97 \cdot 2\end{array}$ & $\begin{array}{r}10 \\
4\end{array}$ & + & $\begin{array}{l}2 \cdot 73 \\
0 \cdot 30\end{array}$ & $\begin{array}{l}3 \cdot 5 \\
2\end{array}$ \\
\hline 64 & $1,25-(\mathrm{OH})_{2} \mathrm{D}_{3}$ & $\begin{array}{l}10 \cdot 24 \\
15 \cdot 34\end{array}$ & $\begin{array}{l}45 \cdot 1 \\
27 \cdot 0\end{array}$ & $\begin{array}{l}38 \cdot 3 \\
21 \cdot 3\end{array}$ & $\begin{array}{l}6 \cdot 83 \\
5 \cdot 71\end{array}$ & $\begin{array}{l}84 \cdot 9 \\
78 \cdot 8\end{array}$ & $\begin{array}{l}6 \\
5\end{array}$ & $\begin{array}{l}+ \\
+\end{array}$ & $\begin{array}{l}4.28 \\
0.97\end{array}$ & $\begin{array}{l}3 \\
1 \cdot 5\end{array}$ \\
\hline 13 & 1-a-OH-D, & $\begin{array}{l}17 \cdot 62 \\
38 \cdot 32\end{array}$ & $\begin{array}{l}11 \cdot 7 \\
15 \cdot 7\end{array}$ & $\begin{array}{r}9 \cdot 4 \\
14 \cdot 7\end{array}$ & $\begin{array}{l}2 \cdot 27 \\
0.98\end{array}$ & $\begin{array}{l}80 \cdot 6 \\
93 \cdot 7\end{array}$ & $\begin{array}{l}5 \\
4\end{array}$ & + & $\begin{array}{l}1 \cdot 27 \\
0.55\end{array}$ & $\begin{array}{l}4 \\
1 \cdot 5\end{array}$ \\
\hline 67 & $1-a-O H-D_{3}$ & $\begin{array}{l}48 \cdot 19 \\
34 \cdot 50\end{array}$ & $\begin{array}{l}21 \cdot 1 \\
10 \cdot 5\end{array}$ & $\begin{array}{l}18 \cdot 7 \\
10 \cdot 4\end{array}$ & $\begin{array}{l}2 \cdot 46 \\
0 \cdot 14\end{array}$ & $\begin{array}{l}88 \cdot 4 \\
98 \cdot 6\end{array}$ & $\begin{array}{l}5 \\
2\end{array}$ & + & $\begin{array}{l}4 \cdot 79 \\
0 \cdot 70\end{array}$ & $\begin{array}{l}4 \cdot 5 \\
2\end{array}$ \\
\hline 78 & $1-\alpha-O H-D_{3}$ & $\begin{array}{l}28 \cdot 49 \\
48 \cdot 68\end{array}$ & $\begin{array}{l}18 \cdot 8 \\
27 \cdot 0\end{array}$ & $\begin{array}{l}12 \cdot 1 \\
13 \cdot 9\end{array}$ & $\begin{array}{r}6 \cdot 74 \\
13 \cdot 10\end{array}$ & $\begin{array}{l}64 \cdot 2 \\
51 \cdot 4\end{array}$ & $\begin{array}{l}6 \\
7\end{array}$ & $\begin{array}{l}+ \\
+\end{array}$ & $\begin{array}{l}2 \cdot 07 \\
3 \cdot 18\end{array}$ & $\begin{array}{l}3 \cdot 5 \\
3 \cdot 5\end{array}$ \\
\hline 82 & $1-a-O H-D_{3}$ & $\begin{array}{l}29 \cdot 76 \\
16 \cdot 24\end{array}$ & $\begin{array}{l}14 \cdot 1 \\
12 \cdot 1\end{array}$ & $\begin{array}{l}13 \cdot 6 \\
11 \cdot 3\end{array}$ & $\begin{array}{l}0.53 \\
0.73\end{array}$ & $\begin{array}{l}96 \cdot 2 \\
94 \cdot 0\end{array}$ & $\begin{array}{l}5 \\
6\end{array}$ & $\begin{array}{l}+ \\
+\end{array}$ & $\begin{array}{l}0.59 \\
0\end{array}$ & $\begin{array}{l}0 \\
0\end{array}$ \\
\hline
\end{tabular}

Table X Details of numbers of marrow mast cells and quantitative bone histology in pre- and post-treatment bone biopsies in nine patients on haemodialysis treated with $1,25-(\mathrm{OH})_{2} D_{3}$ or 1-a-OH- $D_{3}$

The upper and lower sets of data for each patient correspond to pre- and post-treatment biopsies, respectively. Abbreviations as in previous tables.

\begin{tabular}{|c|c|c|c|c|c|c|c|c|c|}
\hline Case & Age/Sex & Disease & $M C$ & $T B$ & $M B$ & $\boldsymbol{O}$ & $\% M I N$ & $\boldsymbol{L}$ & $O F G$ \\
\hline 83 & $25 \mathrm{~F}$ & Vitamin D deficiency & $21 \cdot 79$ & $26 \cdot 9$ & $19 \cdot 6$ & $7 \cdot 26$ & $73 \cdot 0$ & 8 & $1 \cdot 5$ \\
\hline 84 & $41 \mathrm{M}$ & Phosphate diabetes & $10 \cdot 12$ & $45 \cdot 1$ & $25 \cdot 9$ & $19 \cdot 27$ & $57 \cdot 3$ & 17 & 0 \\
\hline 85 & $43 \mathrm{M}$ & Adult coeliac disease & 3.91 & $36 \cdot 5$ & $15 \cdot 1$ & $21 \cdot 44$ & $41 \cdot 3$ & 15 & 2 \\
\hline 86 & $44 \mathrm{~F}$ & Post-gastrectomy osteomalacia & $7 \cdot 36$ & $36 \cdot 0$ & $30 \cdot 5$ & 5.49 & $84 \cdot 8$ & 7 & 1 \\
\hline 87 & $47 \mathrm{M}$ & Adult coeliac disease & $14 \cdot 81$ & $15 \cdot 0$ & $10 \cdot 5$ & 4.53 & $69 \cdot 8$ & 8 & 2 \\
\hline 88 & $54 \mathrm{M}$ & Post-gastrectomy osteomalacia & $1 \cdot 32$ & 20.6 & $18 \cdot 4$ & $2 \cdot 22$ & $89 \cdot 2$ & 7 & 1 \\
\hline 89 & $58 \mathrm{~F}$ & Malabsorption & 6.57 & $15 \cdot 9$ & $12 \cdot 3$ & 3.68 & 76.9 & 8 & $\mathbf{0}$ \\
\hline 90 & $69 \mathrm{~F}$ & Malabsorption & 73.99 & $14 \cdot 1$ & 9.9 & $4 \cdot 24$ & 70.0 & 6 & $1 \cdot 5$ \\
\hline 91 & $71 \mathrm{~F}$ & Malabsorption & & & & & & & \\
\hline & & gastroenterostomy & $58 \cdot 82$ & $21 \cdot 0$ & $15 \cdot 1$ & $5 \cdot 88$ & $71 \cdot 9$ & 6 & 2 \\
\hline 92 & $75 \mathrm{~F}$ & ? Barbiturate osteomalacia & 13.85 & $11 \cdot 3$ & $9 \cdot 0$ & $2 \cdot 26$ & 79.9 & 6 & 1.5 \\
\hline
\end{tabular}

Table XI Marrow mast cell numbers and quantitative bone histology in 10 patients with osteomalacia from a variety of causes excluding chronic renal failure

Abbreviations as in table I. 
row of patients with osteomalacia due to non-renal disease $(P<0.001)$. There is no linear relationship in these 10 patients between the numbers of marrow mast cells and the amounts of total bone, mineralized bone, osteoid or percentage mineralization of cancellous bone ( $P>0 \cdot 10$ in each instance). The increase in mast cell numbers in these patients is of the same order as that observed in the bone biopsies from renal patients whether non-dialysed or haemodialysed. Thus comparison of these three groups of patients reveals no significant difference in mast cell numbers $(P>0 \cdot 10)$. Most of the patients had a mild degree of secondary hyperparathyroidism but there is no consistent relationship between mast cell numbers and the grade of osteitis fibrosa (table XI).

\section{Discussion}

The control bone samples were of necessity obtained at necropsy. We have previously discussed the possibility that better preservation of mast cells, and hence easier recognition, might occur in rapidly fixed bone biopsies in comparison with necropsy specimens in which there is a delay between death and subsequent fixation of tissue (Peart and Ellis, 1975). It was considered that this was an unlikely source of significant error since the marrow mast cells were increased in number in both biopsy and necropsy samples of bone from patients with chronic renal failure. We have since had the opportunity to determine the numbers of marrow mast cells in individual patients coming to necropsy and in whom previous serial bone biopsies were available. In each patient there was close agreement between the marrow mast cell numbers in the biopsy and necropsy specimens. It is concluded that the delay in fixation does not significantly affect the number of recognizable mast cells in the marrow and that the necropsy controls therefore constitute an acceptable reference group.

In the group of 78 patients with chronic renal failure treated by haemodialysis there was an increase in the number of iliac bone marrow mast cells compared with the controls. Treatment by haemodialysis thus seems to have no favourable effect on the increase in marrow mast cell numbers which occurs in chronic renal failure (Peart and Ellis, 1975). There is a tendency for there to be a progressive increase in marrow mast cell numbers with increasing time on dialysis. In some of the present haemodialysed patients there were more marrow mast cells than we had hitherto observed in nondialysed patients with renal failure. Attempts to relate the number of marrow mast cells to the severity of the bone changes, such as osteitis fibrosa and osteomalacia, which may accompany chronic renal failure (Ellis and Peart, 1973) have not been entirely successful.

As far as osteitis fibrosa due to secondary hyperparathyroidism is concerned we have previously shown (Peart and Ellis, 1975) in non-dialysed patients that there is a tendency towards greater numbers of mast cells in those cases with the more severe grades of osteitis fibrosa. This is partly the result of the presence of mast cells in the marrow fibrous tissue forming part of the osteitis fibrosa reaction, but there is also an increase in mast cells in the nonfibrous marrow. By analogy with animal experiments, in which the administration of parathormone appears to be associated with an increase in marrow mast cells (Rockoff and Armstrong, 1970), it could be supposed that the increase in the marrow mast cells in renal failure is the result of increased circulating parathormone from the secondary hyperplastic parathyroid glands. Our present observations on haemodialysed patients have failed to resolve this hypothesis. We have again found that there is a general tendency for the greatest increase in marrow mast cells to occur in those patients with the more severe grades of osteitis fibrosa. However, it must be borne in mind that modifications of the osteitis fibrosa as a result of the haemodialysis or accompanying therapy may make the histological severity of the osteitis fibrosa a poorer index of serum parathormone than it would otherwise have been.

We have had the opportunity to look at the problem from a different viewpoint by studying serial bone biopsies before and after treatment of hyperparathyroidism by parathyroidectomy or by the use of oral aluminium hydroxide. These patients were selected as they showed moderate or more severe degrees of hyperparathyroidism and must not necessarily be regarded as being fully representative of renal bone disease in general in haemodialysed patients. The outcome of these observations was disappointing from the point of view of gaining any understanding of the mechanism for the increased marrow mast cells. Thus although parathyroidectomy or aluminium hydroxide therapy was highly successful in alleviating the histological changes of osteitis fibrosa and was accompanied by appro- $\tilde{N}$ priate biochemical changes, including a reduction in $\mathbb{\omega}^{-}$ circulating parathormone, there was no consistent mast cell response. When we first studied this aspect 0 of the problem by chance we initially examined serial bone biopsies from a parathyroidectomized patient $\stackrel{\oplus}{+}$ (case 35 ) and from one treated with aluminium 7 hydroxide (case 33), both with marked reduction in osteitis fibrosa, and found there was a fall in mast $\stackrel{\mathbb{\Omega}}{\stackrel{D}{\circ}}$ cell numbers. Case 33 appeared to show a good $\stackrel{\mathbb{Q}}{\varrho}$ correlation between the number of marrow mast cells and parathormone output. Thus, following 
aluminium hydroxide treatment over seven months, there was a reduction in serum parathormone, histological resolution of osteitis fibrosa, and a fall in mast cell numbers. After a further seven months another bone biopsy showed a recurrence of the osteitis fibrosa to grade $2 \cdot 5$, an increase of mast cells to 20.55 per $\mathrm{mm}^{2}$ marrow, and a rise in serum parathormone. Our hopes for a significant relationship were not fulfilled when all the patients so treated had been examined. Thus, for example, both responders and non-responders to aluminium hydroxide therapy showed varying increases or reductions in mast cell numbers, and in the 15 patients in whom osteitis fibrosa was improved or resolved and in whom there was an accompanying fall in circulating parathormone, the number of mast cells variably remained unchanged, diminished or increased.

We have also studied the effect on mast cells of improvement in osteitis fibrosa in a small number of patients treated by the vitamin $D$ metabolites $1-\alpha$ $\mathrm{OH}-\mathrm{D}_{3}$ and $1,25-(\mathrm{OH})_{2} \mathrm{D}_{3}$. The details of part of this joint study have been given elsewhere (Pierides et al, 1976b). The treatment was primarily instituted in the belief that it would heal osteomalacia, and it was an unexpected bonus that there should also be a marked beneficial effect on the osteitis fibrosa. It is not clear whether this is solely explicable on the basis of an increase in serum calcium leading to a lowering of parathormone output or, as seems possible, there is a direct effect of $1,25-(\mathrm{OH})_{2} \mathrm{D}_{3}$ on the parathyroid glands. Although seven of the nine patients treated by $1,25-(\mathrm{OH})_{2} \mathrm{D}_{3}$ and $1-\alpha-\mathrm{OH}-\mathrm{D}_{3}$ showed a reduction in the severity of the osteitis fibrosa there was no significant or consistent corresponding change in marrow mast cell numbers. As regards marrow mast cells and osteitis fibrosa we can conclude that there is a tendency for there to be more marrow mast cells in the more severe grades of osteitis fibrosa but we have been unable to prove that there is a significant causal relationship.

Turning to the other important feature of azotaemic renal osteodystrophy, namely osteomalacia, there are again difficulties in interpretation of the data. The number of marrow mast cells is significantly related to the amount of osteoid present and inversely to the percentage mineralization of bone. However, these abnormalities of mineralization and the number of mast cells are also significantly and independently related to the duration of haemodialysis. We are uncertain whether there is a causal relationship between mast cell numbers and mineralization status or whether these are two concurrent effects each independently related to the period of haemodialysis. As explained in the results section above, calculation of the various partial correlation coefficients suggests that there is probably no direct causal relationship between osteomalacia and the number of mast cells and this view is supported by the finding that the number of mast cells does not appear to be related to the presence or absence of osteomalacia. In our previous paper (Peart and Ellis, 1975), when discussing the discrepancy between our failure to correlate mast cell numbers in nondialysed patients with osteomalacia and the reported findings of Rebel et al (1974) that osteomalacia due to any disorder was the probable cause of increased marrow mast cells, we suggested that this might be due to the difference in the duration of osteomalacia. We have now examined serial bone biopsies from haemodialysed patients developing osteomalacia while under observation. Some of these were among those treated by aluminium hydroxide and had developed osteomalacia over relatively short periods. In these there was no accompanying consistent increase in marrow cell numbers. In the case of the patients not receiving aluminium hydroxide there was a significant rise in marrow mast cells but the time interval involved between bone biopsies (during which osteomalacia had developed) was often considerable and significantly greater than for the aluminium hydroxide treated group.

In the light of the discussion above we feel it is just as likely that the mast cell increase is related to the time on dialysis as it is to the development of osteomalacia. From our observations on both dialysed and non-dialysed patients it seems there is no definite correlation between the mineralization status of bone and the number of marrow mast cells. This becomes more problematical in the light of our additional observations in patients with osteomalacia due to a variety of causes such as malabsorption. The increase in marrow mast cells in these patients confirms the report of Rebel et al (1974). The significance of this is uncertain and we are reluctant to accept the suggestion that osteomalacia, whatever the underlying cause, is sufficient to bring about an increase in the number of marrow mast cells. It is difficult to attempt to relate marrow mast cell numbers to osteomalacia or osteitis fibrosa in the bone biopsies of patients with chronic renal failure since both these histological features may be present and may show differing responses to treatment. In the group of patients treated by aluminium hydroxide there was often a reduction of osteitis fibrosa but osteomalacia sometimes became worse or even developed for the first time. If it does transpire that the number of marrow mast cells is related to parathormone output and to osteomalacia then these opposing effects might give rise to no significant change in the number of marrow mast cells for any individual patient treated by aluminium hydroxide.

It would be of interest to know what happens to 
the mast cells in iliac bone marrow of patients suffering from primary hyperparathyroidism where osteitis fibrosa is usually unassociated with osteomalacia. There are already in the literature brief references to marrow mast cells in patients with hyperparathyroidism. Thus Bordier (1970), taking part in the discussion of the paper by Frame and Nixon (1970), mentions that large numbers of mast cells had been seen in the marrow of 14 cases of hyperparathyroidism, and in reply Frame (1970) states that increased mast cells had been found in the bone marrow of three hyperparathyroid patients. Clearly a systematic study of the number of bone marrow mast cells is needed in patients with primary hyperparathyroidism.

The precise relationship between bone marrow mast cell hyperplasia, osteitis fibrosa, osteomalacia, and parathormone still awaits clarification. In seeking a common factor the most likely seems to be parathormone. Thus we have found that there is a tendency in both dialysed and non-dialysed patients with renal failure for there to be most mast cells in those with the more severe degrees of osteitis fibrosa and that mast cells are increased in many of these patients at a time when osteomalacia has not developed. Furthermore, the presence or subsequent development of osteomalacia does not significantly increase the numbers of marrow mast cells. Regarding the mast cell hyperplasia in patients with osteomalacia due to miscellaneous causes one could speculate that this is the result of secondary hyperparathyroidism. Eight of the present 10 patients with non-renal osteomalacia (table XI) had some degree of histological osteitis fibrosa and increased mast cells, while in the remaining two patients there was no marked increase in the numbers of mast cells.

This concept receives some support from experimental animal studies. Rockoff and Armstrong (1970) observed an increase in marrow mast cells in seven of 12 rats injected with parathormone, and Rasmussen (1972) a diminution of mast cells in the marrow of five parathyroidectomized rats. Rasmussen also noted marrow mast cell hyperplasia in hypocalcaemic rats receiving a vitamin $D$ deficient diet or one deficient in both vitamin $\mathbf{D}$ and calcium whereas mast cells were normal in normocalcaemic rats receiving a calcium deficient diet but with vitamin D supplements. Since it is known that hypocalcaemia induces an increase in parathormone output (Potts et al, 1968) this suggests that it is increased parathyroid gland secretory activity in response to hypocalcaemia rather than hypocalcaemia per se which is responsible for the increase in the number of marrow mast cells. We have counted the numbers of marrow mast cells in the tibial metaphysis of 15 control and 11 parathyroid- ectomized rats initially used for a different purpose (Ellis and Peart, 1971a). There was a wide variation in the number of mast cells from field to field in the metaphysis, and to obtain as reliable a result as possible we counted mast cells throughout the metaphysis making due allowance for the proportion occupied by trabeculae of bone and cartilage. The mean values obtained for control and parathyroidectomized rats were $38.8 \pm 13.2$ and $6.1 \pm 1.6$ mast cells per $\mathrm{mm}^{2}$ marrow, respectively, and this difference is just significant $(0.05>P>0.02)$. The younger animals appeared to have most mast cells and there were also sex differences so that a collective analysis is not entirely satisfactory. However, comparison of control and parathyroidectomized rats matched for age and sex did show that in eight of 11 parathyroidectomized animals the number of marrow mast cells was less than the lowest value obtained for the corresponding controls. All these experimental studies support the view that mast cell numbers are related to parathormone but we consider that more comprehensive and critical studies of the effects of both parathormone injections and parathyroidectomy on mast cells are desirable.

Since at this stage we are still uncertain regarding the precise relationship between marrow mast cells and bone disease in renal failure we do not wish to make any further comments on the possible functional relationship between mast cells, heparin, and bone resorption (Peart and Ellis, 1975).

In the present study we have related marrow mast cell numbers to a variety of features of renal bone disease observed in haemodialysed patients. It is therefore necessary to make a few comments on what is sometimes called haemodialysis bone disease. The bone changes in the cases described in this paper are only partly representative of what we have observed in an on-going histological study of some 300 haemodialysed patients. Thus the present series is representative in that there is a progressive increase in the amount of osteoid and incidence of osteomalacia with continuing time on dialysis, but it does not illustrate the reduction in mineralized bone which occurs in some patients. The incidence of osteitis fibrosa and the distribution of the grades of severity are also a little misleading since 20 of the present patients were selected for aluminium hydroxide therapy on the basis of there being a moderate to severe degree of osteitis fibrosa in a pretreatment bone biopsy. In general we can say that socalled dialytic bone disease seems to be variable in its histological manifestations but basically there is underlying osteitis fibrosa due to secondary hyperparathyroidism which is often associated with a mineralization defect. Both these changes are, of 
course, features of azotaemic renal osteodystrophy in non-dialysed patients, and what one finds will to some extent depend upon the state of the bone at the onset of dialysis. In dialysed patients there is sometimes an initial modification of the osteitis fibrosa and although resorption of mineralized bone continues there seems to be a reduction in the repair reaction so that there is less accompanying woven bone formation or marrow fibrosis than one would have anticipated (Ellis and Peart, 1971b). The amount of total bone is variable, and may be reduced, normal or increased. In some long-term haemodialysed patients with raised total bone the increase is largely the result of an increase in osteoid, and the subjacent mineralized bone shows evidence of resorption and is reduced in amount. Administration of aluminium hydroxide or vitamin $\mathbf{D}$ metabolites will modify the histology, and osteomalacia may be worsened by barbiturates (Pierides et al, 1976a). One of the present patients (case 78), treated with $1-\alpha-O H-D_{3}$ and in whom there was no improvement of osteitis fibrosa or osteomalacia, had also received barbiturates. We believe (Pierides and Ellis, 1975) that this lack of response might have been due to barbiturate interference with the normal hepatic hydroxylation of $1-\alpha-\mathrm{OH}-\mathrm{D}_{3}$ by druginduced enhancement of hepatic microsomal enzyme activity. In this respect, it is interesting to note that Chan et al (1975) found that 1- $\alpha-\mathrm{OH}-\mathrm{D}_{3}$ did not depress serum parathormone in a patient also receiving anticonvulsants, and that another patient given $1-\alpha-O H-D_{3}$ initially showed a fall in serum alkaline phosphatase but a later rise in this enzyme when phenytoin therapy was started.

In conclusion it can be said that mast cells are increased in number in the marrow of patients suffering from chronic renal failure and that this is not favourably influenced by long-term haemodialysis. This increase is not specific to renal failure since it occurs in patients with osteomalacia due to other causes. It is tempting to relate the increase in mast cells to some systemic or local effect which bears directly on the histopathological bone changes but we have been unable to relate consistently either osteitis fibrosa or a mineralization defect to the numbers of marrow mast cells in our patients with chronic renal failure. It may be that the common factor to marrow mast cell hyperplasia and osteomalacia in non-renal diseases or to osteitis fibrosa with or without osteomalacia in renal diseases is the secondary parathyroid hyperplasia and increased parathormone output which occurs in these patients. The limited evidence from animal experiments, such as the increase in the number of marrow mast cells following the administration of parathormone and the reduction in mast cells after parathyroidectomy, is in keeping with this hypothesis. We have been unable so far to resolve this problem by observations on patients, and particularly noteworthy in this respect is our failure to find a consistent reduction in marrow mast cell numbers following sucessful alleviation of hyperparathyroidism by parathyroidectomy or aluminium hydroxide therapy. Possibly a full explanation is not to be found in the parathyroid-bone context and it would be worthwhile considering other features such as the general increase in marrow cellularity or even those outwith the bone altogether. In this respect it should be borne in mind that mast cells may be increased in renal failure in a number of other organs such as the spleen and kidney (Neiman et al, 1972; Colvin et al, 1974).

We wish to acknowledge the help of many of our colleagues in the Department of Medicine and in particular we are indebted to Dr A. M. Pierides, Professor D. N. S. Kerr, Dr A. V. L. Hill, and Dr F. Alvarez-Ude. 1- $\alpha-O H-D_{3}$ was generously supplied by Dr H. F. De Luca, Department of Biochemistry, University of Wisconsin, Madison, USA. We also wish to thank Mrs D. Weightman of the Department of Medical Statistics for statistical advice and $\mathrm{Mr} \mathbf{H}$. Elliott for valuable technical assistance. The help of Miss E. Wark with the typescript and $\mathrm{Mr}$ W. Robinson with the photographs is gratefully acknowledged. One of us (KMP) is in receipt of a (Medical Research Council Grant (No. G973/693/C.)

\section{References}

Baker, L. R. I., Ackrill, P., Cattell, W. R., Stamp, T. C. B. and Watson, L. (1974). Iatrogenic osteomalacia and myopathy due to phosphate depletion. Brit. med.J., 3, 150-152.

Bordier, P. (1970). Discussion of paper by Frame, B., and Nixon, R. K. In Osteoporosis, edited by U. S. Barzel, p. 249. Grune and Stratton, New York and London.

Chan, J. C. M., Oldham, S. B., Holick, M. F., and DeLuca, H. F. (1975). 1-a-Hydroxyvitamin $D_{3}$ in chronic renal failure: a potent analogue of the kidney hormone, 1, 25dihydroxycholecalciferol. J. Amer. med. Ass., 234, 47-52.

Colvin, R. B., Dvorak, A. M., and Dvorak, H. F. (1974). Mast cells in the cortical tubular epithelium and interstitium in human renal disease. Hum. Path., 5, 315-326.

Ellis, H. A. (1973). Bone disease in end-stage renal failure. (Letter). Brit. med. J., 3, 232-233.

Ellis, H. A. and Peart, K. M. (1971a): Dextran sulphate osteopathy in parathyroidectomised rats. Brit.J. exp. Path., 52, 684-695.

Ellis, H. A. and Peart, K. M. (1971b). Renal osteodystrophy with particular reference to the effects of chronic intermittent haemodialysis (abstract). Nephron, 8, 402.

Ellis, H. A. and Peart, K. M. (1972). Quantitative observations on mineralized and non-mineralized bone in the iliac crest. J. clin. Path., 25, 277-286.

Ellis, H. A. and Peart, K. M. (1973). Azotaemic renal osteodystrophy: a quantitative study on iliac bone. $J$. clin. Path., 26, 83-101.

Frame, B. (1970). Discussion of paper by Frame, B., and 
Nixon, R. K. In Osteoporosis, edited by U. S. Barzel, p. 249. Grune and Stratton, New York and London.

Frame, B. and Nixon, R. K. (1970). Bone marrow factors in osteoporosis. In Osteoporosis, edited by U. S. Barzel, pp. 238-250. Grune and Stratton, New York and London.

Garner, A. and Ball, J. (1966). Quantitative observations on mineralised and unmineralised bone in chronic renal azotaemia and intestinal malabsorption syndrome. J. Path. Bast., 91, 545-561.

Gilmour, J. R. (1947). The Parathyroid Glands and Skeleton in Renal Disease. Cumberlege, Oxford University Press, London.

Hill, A. V. L., Alvarez-Ude, F., Pierides, A. M., Kerr, D. N. S., Ellis, H. A., and Peart, K. M. (1975). The effects of calcium carbonate (CC), aluminium hydroxide (AH) and dihydrotachysterol (DHT) on haemodialysis bone disease. In Proceedings of the Second Workshop on Vitamin D, Wiesbaden, 1974, edited by A. W. Norman, K. Schaefer, H. G. Grigoleit, D. V. Herrath, and E. Ritz, pp. 643-650. Walter de Gruyter, Berlin.

Neiman, R. S., Bischel, M. D., and Lukes, R. J. (1972). Uraemia and mast cell proliferation. Lancet, 1, 959.

Peart, K. M. and Ellis, H. A. (1975). Quantitative observations on iliac bone marrow mast cells in chronic renal failure. J. clin. Path., 28, 947-955.

Pierides, A. M. and Ellis, H. A. (1975). Unpublished observations.

Pierides, A. M. Ellis, H. A., Ward, M. K., Simpson, W., Peart, K. M., Alvarez-Ude, F., Uldall, P. R., and Kerr,
D. N. S. (1976a). Barbiturate and anticonvulsant treatment in relation to osteomalacia with haemodialysis and renal transplantation. Brit. med. J., 1, 190-193.

Pierides, A. M., Ward, M. K., Alvarez-Ude, F., Ellis, H. A., Peart, K. M., Simpson, W., Kerr, D. N. S., and Norman, A. (1976b). Long term therapy with $1,25(O H)_{2} D_{3}$ in dialysis bone disease. In Proceeding of the European $\overline{\bar{c}}$ Dialysis and Transplant Association, Copenhagen, 1975, $\vec{\oplus}$ vol. 12, edited by J. F. Moorhead, R. A. Baillod, and C. @ Mion, pp. 237-244. Pitman, London.

Potts, J. T., Jr., Buckle, R. M., Sherwood, L. M., Ramberg, C. F., Jr., Mayer, C. P., Kronfeld, D. S., Deftos, L. J., ? Care, A. D., and Aurbach, G. D. (1968). Control of $\vec{t}$ secretion of parathyroid hormone. In Parathyroid Hormone $\vec{\omega}$ and Thyrocalcitonin (Calcitonin) (International Congress Series, No. 159), edited by R. V. Talmage and L. F. Bélanger, pp. 407-416. Excerpta Medica Foundation, Amsterdam.

Rasmussen, P. (1972), An experimental study of mast cells in the rat metaphysis. Calcif. Tiss. Res., 9, 325-330.

Rebel, A., Riberi, P., Bregeon, P., and Malkani, K. (1974). N Mastocytes et remaniements du tissue osseux. Path. et 응 Biol., 22, 213-220.

Rockoff, S. D. and Armstrong, J. D., Jr. (1970). Parathyroid hormone as a stimulus to mast cell accumulation in bone. Calcif. Tiss. Res., 5, 49-55.

Snedecor, G. W. and Cochran, W. G. (1971). Statistical Methods, 6th edition, p. 130. Iowa State University Press, Ames, Iowa. 